\title{
Management of Apple Maturity and Postharvest Storage Conditions to Increase Polyphenols in Cider
}

\author{
Brianna L. Ewing ${ }^{1}$ \\ Department of Food Science and Technology, Virginia Polytechnic Institute \\ and State University, 260 Duckpond Drive, Blacksburg, VA 24061
}

Gregory M. Peck

School of Integrative Plant Science, Horticulture Section, Cornell University, 121 Plant Science Building, Ithaca, NY 14850

\author{
Sihui Ma, Andrew P. Neilson, and Amanda C. Stewart ${ }^{2}$ \\ Department of Food Science and Technology, Virginia Polytechnic Institute \\ and State University, 260 Duckpond Drive, Blacksburg, VA 24061
}

Additional index words. Malus $\times$ domestica Borkh., tannin, procyanidin, flavanol, 'Dabinett', 'Binet Rouge', 'York', 'GoldRush'

\begin{abstract}
Hard cider production in the United States has increased dramatically during the past decade, but there is little information on how harvest and postharvest practices affect the chemistry of the resulting cider, including concentrations of organoleptically important flavanols. For 2 years we assessed fruit, juice, and cider from a total of five apple (Malus $\times$ domestica Borkh.) cultivars in two experiments: sequential harvests and postharvest storage. Different cultivars were used in 2015 and 2016 with the exception of 'Dabinett', which was assessed in both years. There were no differences in polyphenol concentrations in cider made from fruit that was harvested on three separate occasions over a 4-week period in either 2015 or 2016. Fruit storage durations and temperatures had little influence on the chemistry when the experiment was conducted in 2015 , but polyphenol concentration was greater after storage in the 2016 experiment. In 2016, total polyphenols in 'Dabinett' ciders were $51 \%$ greater after short-term storage at $10{ }^{\circ} \mathrm{C}$ and $67 \%$ greater after long-term storage at $1{ }^{\circ} \mathrm{C}$ than the control, which was not subjected to a storage treatment. In 2016, total polyphenols in 'Binet Rouge' ciders were $67 \%$ greater after short-term storage at $10{ }^{\circ} \mathrm{C}$ and $94 \%$ greater after long-term storage at $1{ }^{\circ} \mathrm{C}$ than the control. Although results varied among cultivars and harvest years, storing apples for longer periods of time and at warmer temperatures may be a strategy to increase polyphenol, particularly flavanol, concentrations in hard cider.
\end{abstract}

Hard cider, or simply "cider," is the alcoholic beverage made from apple (Malus $\times$ domestica Borkh.) juice. In 2016, U.S. cider sales were $\approx 1.3 \%$ the market share of beer, but between 2011 and 2016, cider sales increased $27.3 \%$ per year, making it the fastest growing sector in the alcohol beverage market during that time frame (Brager and Crompton, 2017; Petrillo, 2016).

Cider can be made from any apple cultivar, but cultivars vary greatly in terms of chemical components that contribute to the

\footnotetext{
Received for publication 7 Nov. 2018. Accepted for publication 15 Aug. 2018.

This work was supported by the Virginia Wine Board project titled "Managing Apple Maturity and Post-Harvest Regimes to Increase Quality of Virginia's Ciders."

We are thankful for the assistance provided by Abby Kowalski, Ken Hurley, and Ann Sandbrook. ${ }^{1}$ Current address: School of Food Science, Washington State University, Northwestern Washington Research and Extension Center, 16650 State Route 536, Mount Vernon, WA 98273

${ }^{2}$ Corresponding author. E-mail: amanda.stewart@ vt.edu.
}

bark, or nuts (Lea and Piggott, 2012; Martin et al., 2017). Therefore, it is important to develop strategies, perhaps through harvest and storage management practices, that maximize the concentration of endogenous tannins in the fruit.

Polyphenols are a class of secondary plant metabolites derived through the phenylpropanoid pathway that perform a wide range of functions, including being structural building blocks and providing both biotic and abiotic protection to plants. A subset of polyphenols, informally referred to as tannins, also lend important sensory perceptions to foods and beverages, including taste and color (Spanos and Wrolstad, 1992). Apple polyphenols can be classified into five main groups: phenolic acids, flavanols, anthocyanins, flavonols, dihydrochalcones (Guyot et al., 2003; Nicolas et al., 1994; Spanos and Wrolstad, 1992). Chlorogenic acid (CLA) is the most abundant of the phenolic acids reported in apples (Guyot et al., 1998). The flavanols consist of the monomers $(+)$-catechin (CAT) and $(-)$-epicatechin (EPI), and procyanidins (also referred to as condensed tannins), which are the oligomers of monomers (Guyot et al., 2003; Verdu et al., 2014; Vidal et al., 2003). Anthocyanins are another group of polyphenols responsible for skin pigmentation in red cultivars (Nicolas et al., 1994). However, anthocyanins are a minor source of flavor or olfactory perception. Flavonols [mainly quercetin (QUE) derivatives] and dihydrochalcones [mostly phloretin (PHL) derivatives] are relatively minor contributors to pigmentation and are present in relatively much lower concentrations than flavanols and phenolic acids (Guyot et al., 1998; Renard et al., 2007; Sanoner et al., 1999).

It has been reported that flavanols and phenolic acids are formed primarily during the cell division phase during the early development of the apple, then decrease in concentration during fruit growth and maturation (Mosel and Herrmann, 1974; Renard et al., 2007). In many regions where cider apples are grown, fruit are allowed to mature on the tree until they senesce and drop to the ground. Cider apples also have a greater potential for mechanical harvesting compared with fresh-market apples, because bruises and blemishes from the process are not detrimental to processing quality (Merwin et al., 2008; Miles and King, 2014). These apples are usually fully ripemeaning, most, if not all, of the starch has hydrolyzed to sugars. In the United States, most apples used for cider are harvested by hand at a much earlier maturity stage, typically when $20 \%$ to $60 \%$ of starch hydrolysis has occurred. This allows for longer storage durations, which is desirable for providing fruit year-round for the fresh-market supply chain, but the extent to which harvesting apples at an earlier maturity affects polyphenols that are important for the sensory quality of ciders remains unknown.

Effects of fruit storage duration and temperature on polyphenol chemistry of cider apples, juice, and cider are also unknown. 
Studies on polyphenols in cold-stored apples have reported varied effects. A study by van der Sluis et al. (2001) measured glycosidic forms of polyphenols in apples and found that cold storage for 25 weeks did not induce significant changes in QUE glycosides, phloridzin (a glucosidic form of PHL), cyanidin galactosides, or CLA concentrations. There was, however, a slight decrease in CAT concentrations during storage for some cultivars in some harvest years (van der Sluis et al., 2001). Burda et al. (1990) also found that polyphenol concentrations remained relatively constant during fruit storage, whereas other studies resulted in documented increases in total polyphenols or antioxidant capacity during fruit storage (Burda et al., 1990; Leja et al., 2003; Napolitano et al., 2004). It appears that both the apple genotype and the preharvest conditions that change each year (e.g., crop load, heat units, water or heat stress, nutrient status) are potentially interacting factors influencing the effects of postharvest storage on polyphenol content in apples.

Furthermore, some cider makers will ripen apples at ambient temperatures for 2 to 4 weeks after harvest (Lea and Piggott, 2012). This process is referred to colloquially as sweating. During this process, sugar levels and flavor volatiles may increase as acidity and water content decrease. For these reasons, it is important to examine how the storage of apples destined for cider production affects the concentration and composition of polyphenols.

The objectives of this study were to determine how harvest and postharvest practices affect cider chemistry - specifically, polyphenol and flavanol concentrations. In one experiment, fruit was harvested at three time points, starting when the fruit was preclimacteric (as measured by ethylene production) and at two additional sequential harvest dates at 2-week intervals. In a second experiment, fruit from a single harvest date was stored under different storage durations and temperatures. We hypothesized that later harvests and longer storage durations would maximize the concentration of organoleptically important polyphenols in fruit, juice, and cider.

\section{Materials and Methods}

Fruit selection. Two separate experiments were conducted in each of two years: 2015 and 2016. Within each year, both experiments used the same cultivars, but different trees within the same orchard. In 2015, the cultivars Dabinett, a British bittersweet cider cultivar, and York Imperial, a sharp culinary cultivar, were used. In 2016, Dabinett, Binet Rouge, a French bittersweet cider cultivar, and GoldRush, a sharp culinary cultivar, were used. These cultivars were chosen to compare the effects of harvest maturity and storage treatments on both high- and lowtannin cultivars. Different apple cultivars had to be used in 2015 and 2016 because of their biennial bearing habit. The 'Dabinett' and 'Binet Rouge' apples were grown on trees planted in 2003 and grafted on 'Malling 9' ('M.9') or Geneva 9 ('G.30') rootstocks, and the 'GoldRush' apples were grown on trees planted in 1996 and grafted on Malling 7 ('M.7') rootstock at the Cornell University Agricultural Experiment Station in Lansing, NY. The cultivar York Imperial (Ramey), referred to as "York" in this study, was grown on trees planted in 2000 and grafted on 'M.9' rootstocks at Virginia Tech's Alson H. Smith, Jr. Agricultural Research and Extension Center in Winchester, VA.

Experimental design. For each experiment in each year, there were four singletree replicates per treatment per cultivar. For the harvest maturity experiment, fruit was harvested in about 2-week intervals $(\mathrm{H} 1, \mathrm{H} 2$, and H3), with harvest dates listed in Table 1. For this experiment, about one-third of the total yield was harvested randomly but equally from all fruiting regions (top, each side of the row, and in the interior of the canopy) of the sample tree at each harvest. The effect of reducing the crop load through these sequential harvests on juice and cider chemistry was not examined.

For the storage experiment, all the fruit from each tree was harvested in a single pick (Table 1), brought into the laboratory, and then divided randomly into four groups - one for each postharvest treatment. The fruit from each tree was kept separate throughout the process and handled the same until the storage treatments were imposed. The fruit was then separated into various walk-in coolers for the storage treatments as follows: control, "short-term" storage of 6 weeks at $1{ }^{\circ} \mathrm{C}(\mathrm{S}-1 \mathrm{C})$, "short-term" storage of 6 weeks at $10^{\circ} \mathrm{C}(\mathrm{S}-10 \mathrm{C})$, and "long-term" storage of $\approx 4$ months at $1{ }^{\circ} \mathrm{C}(\mathrm{L}-1 \mathrm{C})$. Harvest and processing dates are presented in Table 1 . The S-10C treatment was meant to simulate a traditional sweating process. The $\mathrm{L}-1 \mathrm{C}$ treatment was chosen to replicate commercial long-term cold storage.

Fruit analysis. Fruit firmness, weight, starch, color, and ethylene concentration were measured on a 10- apple subsample per experimental unit (tree $\times$ harvest date treatment for Expt. 1 and tree $\times$ postharvest storage treatment for Expt. 2). Fruit analysis procedures followed those described in Thompson-Witrick et al. (2014). Briefly, apples were weighed and then a $1-\mathrm{mL}$ gas sample was removed from the core cavity of each apple with a syringe and injected into an Agilent 7890 gas chromatograph equipped with a flame ion detector set at $250{ }^{\circ} \mathrm{C}$ (Agilent Technologies, Wilmington, DE). The inlet temperature was $220{ }^{\circ} \mathrm{C}$, oven temperature was $50{ }^{\circ} \mathrm{C}$, and we used a GSAlumina $30 \mathrm{~m} \times 0.252 \mathrm{~mm}$ GS-Alumina column (Agilent Technologies). Flesh firmness was measured at two points at the equator of the apple after the peel was removed using a Fruit Texture Analyzer penetrometer [Güss Manufacturing (Pty.) Ltd., Strand, S.A.] fitted with a cylindrical 11.1-mm-diameter tip. Starch pattern iodine index (SPI) was determined by staining the stem-side cross-section of an apple sliced equatorially with a $0.22 \%$ iodine and $0.88 \%$ potassium iodine $(\mathrm{w} / \mathrm{v})$ solution, and rating on the Cornell Starch-Iodine
Index $1-8$ scale, where $1=100 \%$ staining (minimal starch hydrolysis) and $8=0 \%$ staining (complete starch hydrolysis) (Blanpied and Silsby, 1992).

Juice analysis and preparation. The 10 subsamples were pooled together and the calyx half of each apple was juiced (The Champion Juicer, model G5-PG-710; Plastaket Mfg. Inc., Lodi, CA). Samples were stored at $-80{ }^{\circ} \mathrm{C}$ until analysis. Soluble solid content (SSC) was measured with a digital refractometer (PAL-1; Atago U.S.A., Inc., Bellevue, WA) and is reported in ${ }^{\circ}$ Brix. The $\mathrm{pH}$ was measured using a $\mathrm{pH}$ probe (Thermo Scientific Versa Star Benchtop Meter, model VSTAR30; Thermo Scientific ROSS Ultra Triode Electrode, model 8107BNUMD; Thermo Scientific, Waltham, MA). Titratable acidity (TA) was measured by titrating against a $0.1 \mathrm{~N}$ $\mathrm{NaOH}$ solution to an endpoint of $\mathrm{pH} 8.2$ and is reported as malic acid equivalents (Iland, 2004). Total polyphenol content was measured using the Folin-Ciocalteu method and is reported as gallic acid equivalents (Waterhouse, 2002). Primary amino nitrogen (PAN) was measured using the ultraviolet method with a Megazyme Primary Amino Nitrogen kit (Megazyme International, Ireland) (Dukes and Butzke, 1998). Yeast assimilable nitrogen refers to the nitrogenous compounds able to be used through yeast metabolism and is comprised of ammonium and PAN. PAN is a measure of the primary amino acid source of yeast assimilable nitrogen (Bell and Henschke, 2005). The juice chemistry parameters $\mathrm{pH}, \mathrm{TA}, \mathrm{SSC}$, total polyphenols, and PAN are common measurements performed by cider producers.

Juice was prepared for fermentation using standard cider industry practices. Pectinase was added for prefermentation clarification (Pec5L, Scottzyme; Scott Laboratories, Petaluma, CA) at $1 \mu \mathrm{L} / 100 \mathrm{~mL}$ juice and allowed to settle overnight in an $18{ }^{\circ} \mathrm{C}$ temperaturecontrolled room. After settling, $750 \mathrm{~mL}$ of the clarified juice was racked into autoclaved $1000-\mathrm{mL}$ erlenmeyer flasks for fermentation. Potassium metabisulfite (KMB; Presque Isle Wine Cellars, North East, PA) was added to the juice at $30 \mathrm{mg} / \mathrm{L} 3 \mathrm{~h}$ before inoculation with yeast.

Fermentation. Lalvin EC1118 yeast (Scott Laboratories) was rehydrated in $40{ }^{\circ} \mathrm{C}$ deionized water and added to juice according to the manufacturer's recommended procedure at $250 \mathrm{mg} / \mathrm{L}$. After inoculation, Fermaid ${ }^{\circledR} \mathrm{K}$ posthydration nutrient (Scott Laboratories) was added to each flask at $24 \mathrm{~g}$ nutrient $/ \mathrm{L}$ juice. Rubber bungs and airlocks, sanitized with a KMB and citric acid solution, were used to seal the flasks so that $\mathrm{CO}_{2}$ gas could escape during the fermentation process, but oxygen and other contaminants could not enter the fermenting sample. The flasks were placed in a temperature-controlled incubation chamber at $18^{\circ} \mathrm{C}$ for the duration of the fermentation process.

Fermentation rates were monitored by weighing the flasks daily. A decrease in mass is observed as a result of the production and expulsion of $\mathrm{CO}_{2}$ gas (produced as a 
Table 1. Harvest dates for the maturity study and storage durations for the storage study for each cultivar for each year of the study.

\begin{tabular}{|c|c|c|c|c|c|c|c|c|}
\hline \multirow[b]{3}{*}{ Cultivar } & \multirow{2}{*}{\multicolumn{3}{|c|}{$\begin{array}{c}\text { Maturity expt. }^{\mathrm{z}} \\
\text { Harvest date }\end{array}$}} & \multicolumn{5}{|c|}{ Storage expt. ${ }^{y}$} \\
\hline & & & & \multirow[b]{2}{*}{ Harvest date } & \multicolumn{4}{|c|}{ Date processed } \\
\hline & $\mathrm{H} 1$ & $\mathrm{H} 2$ & H3 & & $\mathrm{CON}$ & S-1C & $\mathrm{S}-10 \mathrm{C}$ & L-1C \\
\hline$\overline{\mathrm{YK} / 2015}$ & 11 Sept. & 25 Sept. & 9 Oct. & 25 Sept. & 6 Oct. & 19 Nov. & 19 Nov. & 27 Jan. \\
\hline $\mathrm{DB} / 2015$ & 9 Sept. & 23 Sept. & 6 Oct. & 23 Sept. & 6 Oct. & 19 Nov. & 19 Nov. & 27 Jan. \\
\hline $\mathrm{GR} / 2016$ & 19 Oct. & 1 Nov. & 16 Nov. & 26 Oct. & 27 Oct. & 7 Dec. & 7 Dec. & $28 \mathrm{Feb}$. \\
\hline $\mathrm{DB} / 2016$ & 15 Sept. & 30 Sept. & 12 Oct. & 28 Sept. & 28 Sept. & 7 Nov. & 8 Nov. & 26 Jan. \\
\hline$\underline{\mathrm{BR} / 2016}$ & 15 Sept. & 30 Sept. & 12 Oct. & 28 Sept. & 28 Sept. & 7 Nov. & 8 Nov. & 26 Jan. \\
\hline
\end{tabular}

${ }^{\mathrm{z}}$ Sequential harvest dates are designated $\mathrm{H} 1, \mathrm{H} 2$, and $\mathrm{H} 3$.

${ }^{\mathrm{y}}$ Storage treatments included a control $(\mathrm{CON})$, "short-term" storage at $1{ }^{\circ} \mathrm{C}(\mathrm{S}-1 \mathrm{C})$, "short-term" storage at $10{ }^{\circ} \mathrm{C}(\mathrm{S}-10 \mathrm{C})$, and "long-term" storage at $1{ }^{\circ} \mathrm{C}$ (L-1C).

$\mathrm{YK}=$ 'York'; DB = 'Dabinett'; GR = 'GoldRush'; BR = 'Binet Rouge'.

byproduct of fermentation by yeast) from the vessel. When the mass loss stabilized, a 0.10$\mathrm{mL}$ sample was used for determination of residual sugar concentration by enzymatic reducing sugar analysis using the Megazyme D-Fructose/D-Glucose assay kit (Megazyme International). Fermentation was considered complete and stopped when the residual sugar concentration was between 0.2 and $0.5 \mathrm{~g} / \mathrm{L}$

Sample collection and storage. Upon completion of the fermentation process, cider was collected in $50-\mathrm{mL}$ and $15-\mathrm{mL}$ centrifuge tubes. Additional samples for analysis of individual phenolic compounds were collected in 2-mL sample tubes with four parts sample and one part preservative $(4.7 \%$ glacial acetic acid and $0.02 \% \mathrm{w} / \mathrm{v}$ ascorbic acid) to prevent oxidation of polyphenols (Thompson-Witrick et al., 2014). All samples were stored at $-80{ }^{\circ} \mathrm{C}$ until analysis, at which point they were thawed in a refrigerator and then brought to room temperature before analysis.

Cider analysis. Residual sugar, $\mathrm{pH}$, TA, PAN, and total polyphenols were measured as described earlier. Cider individual polyphenols were analyzed using an ultra-high performance liquid chromatography/mass spectrometry (UPLC/MS) system with Empower software (UPLC-QDA; Waters Corporation, Milford, MA). The AQUITY UPLC HSS T3 column $(2.1 \mathrm{~mm} \times 100 \mathrm{~mm}, 1.8 \mu \mathrm{m}$; Waters Corporation) was used in combination with an AQUITY UPLC HSS T3 $(2.1 \times$ $5 \mathrm{~mm}, 1.7 \mu \mathrm{m}$ ) VanGuard precolumn (Waters Corporation). The initial mobile phase was prepared using $95 \%$ of Mobile Phase A and 5\% Mobile Phase B. Mobile Phase A consisted of $0.1 \%$ formic acid (Macron Fine Chemicals, Avantor Performance Materials Inc., Center Valley, PA) in high-performance liquid chromatography-grade water (Synergy HPLC Water Purification System; EMD Millipore, Billerica, MA) and Mobile Phase $\mathrm{B}$ consisted of $0.1 \%$ formic acid in acetonitrile (J.T. Baker, Avantor Performance Materials Inc., Center Valley, PA). Once thawed, $1 \mathrm{~mL}$ of the cider-preservative solution was pipetted into $50-\mathrm{mL}$ centrifuge tubes and flushed immediately with nitrogen gas for $\approx 5 \mathrm{~s}$ to limit oxidation of polyphenols further. Then, $1 \mu \mathrm{L}$ of a single sample was pipetted onto $\mathrm{pH}$ paper to approximate the $\mathrm{pH}$ of the original sample. Because polyphenols in juice and cider are commonly found in their glyco- sidic forms, acid hydrolysis of glycosides was performed to allow the measurement of the total concentration of each polyphenol (including all glycosidic-bound forms present) using a single standard for the unbound compound to quantify all forms of a given polyphenol present in the sample. The $\mathrm{pH}$ of all samples was then adjusted to $\approx 2.0$ using $1 \mu \mathrm{L}$ of $1 \mathrm{M} \mathrm{HCl}$ and then subsequently flushed with nitrogen. Samples were then hydrolyzed in an oven at $100{ }^{\circ} \mathrm{C}$ for $10 \mathrm{~min}$ to render polyphenols from their glycosidic to aglycone forms. Samples were kept on ice until extraction.

After cooling samples on ice for several minutes, $2 \mathrm{~mL}$ ethyl acetate was added to the hydrolyzed sample to extract the polyphenols from the solution. Samples were vortexmixed and the layers were then allowed to separate for $30 \mathrm{~s}$. The top ethyl acetate layer was collected because this layer contained the polyphenols used for analysis. Extraction was repeated three times for each sample. The pooled ethyl acetate layer was dried under nitrogen gas (to avoid oxidation) at room temperature using the N-EVAP 111 Nitrogen Evaporator (Organomation, Berlin, MA) on low heat until the sample was dry. Dried samples were stored at $-80{ }^{\circ} \mathrm{C}$ until analysis. Samples were then reconstituted in $1 \mathrm{~mL} \mathrm{95 \%} \mathrm{Mobile} \mathrm{Phase} \mathrm{A} \mathrm{and} \mathrm{5 \%} \mathrm{Mobile}$ Phase B, then filtered using 1-mL Luer-Lok Syringe Tips (BD, Franklin Lakes, NJ) and $0.22-\mu \mathrm{m}$ polytetrafluoroethylene filters (MicroSolv, Eatontown, NJ) into $12 \times 33$-mm UPLC/ MS vials (Waters Corporation).

Standards and samples were incubated in the autosampler at $4{ }^{\circ} \mathrm{C}$ and injected into the column in $10-\mu \mathrm{L}$ volumes and eluted at $43{ }^{\circ} \mathrm{C}$. The flow rate was $0.6 \mathrm{~mL} / \mathrm{min}$. The probe temperature was $600{ }^{\circ} \mathrm{C}$, the capillary voltage was $0.8 \mathrm{kV}$, the ionization mode was ESI-, and each compound was identified by its retention time, molecular weight, and single ion recording (SIR) channel (Supplemental Table 1). Peaks were analyzed using the Apex Track function of Empower software and were smoothed using a mean smoothing level of nine.

The standards used were CAT, EPI, CLA, QUE, PHL (Sigma-Aldrich, St. Louis, MO); and procyanidin $\mathrm{B} 1$ (PCB1), procyanidin $\mathrm{B} 2$ (PCB2), procyanidin B5 (PCB5), procyanidin $\mathrm{C} 1$ (PCC1), and cinnamtannin A2 (CA2) (Planta Analytica, Danbury, CT). These standards were chosen because of their known presence in apples as well as their importance in sensory and health studies (Lu and Foo, 1997; Vrhovsek et al., 2004). Standards were prepared from a $0.1-\mathrm{mg} / \mathrm{mL}$ standard in methanol solution stored at $-80{ }^{\circ} \mathrm{C}$ until analysis. A serial dilution using 95\% Mobile Phase A and 5\% Mobile Phase B was then completed to obtain a total of eight calibration standards.

Statistical analysis. One-way analysis of variance was used to determine the individual effects of treatment (harvest date or postharvest storage condition) and cultivar using the software GraphPad Prism (version 6; La Jolla, CA), with significance defined as $P<$ 0.05 . Each replication (tree) was considered a random effect. Mean separation was by Tukey's honestly significant difference test at $P \leq 0.05$. Differences were calculated within each cultivar and not between cultivars.

\section{Results}

Harvest maturity effects on fruit, juice, and cider. Fruit firmness, weight, starch, color, and ethylene concentrations were measured to determine whether changes in fruit characteristics resulted from the treatments (Supplemental Tables 2-6). For three of the five cultivars (2015 'York', 2015 'Dabinett', 2016 'GoldRush') measured in the 2 years, ethylene concentration increased from the first to the third harvest. All measured cultivars increased in SPI from the first to the third harvest, but SSC increased only in one cultivar (2016 'GoldRush'). For three of five cultivars, fruit firmness decreased (2015 'York', 2015 'Dabinett', 2016 'GoldRush'), and for four of five cultivars (2015 'York', 2015 'Dabinett', 2016 'Dabinett', 2016 'Binet Rouge'), fruit weight increased. Neither $\mathrm{pH}$ nor TA was greatly affected by harvest maturity date When measured in juice at harvest, total polyphenol concentration showed inconsistent trends, with 'York' in 2015 and 'Binet Rouge' in 2016 decreasing in concentration from the first to third harvests, but 'GoldRush' in 2016 increasing, and 'Dabinett' in 2015 and 2016 not changing with harvest date. Similarly, the effect of harvest maturity on PAN concentration was inconsistent among the five cultivars.

Cider $\mathrm{pH}$, TA, and total polyphenol concentration did not vary among treatments in any of the ciders from either harvest year. Ethanol concentration did not differ significantly among treatments in the 2015 ciders or the 2016 'Binet 
Table 2. 2016 'Dabinett' (DA) and 'Binet Rouge' (BR) fruit, juice, and cider results from the control (CON), storage for 6 weeks at $1{ }^{\circ} \mathrm{C}(\mathrm{S}-1 \mathrm{C})$, storage for six weeks at $10^{\circ} \mathrm{C}(\mathrm{S}-10 \mathrm{C})$, and storage for 4 months at $1{ }^{\circ} \mathrm{C}(\mathrm{L}-1 \mathrm{C})$.

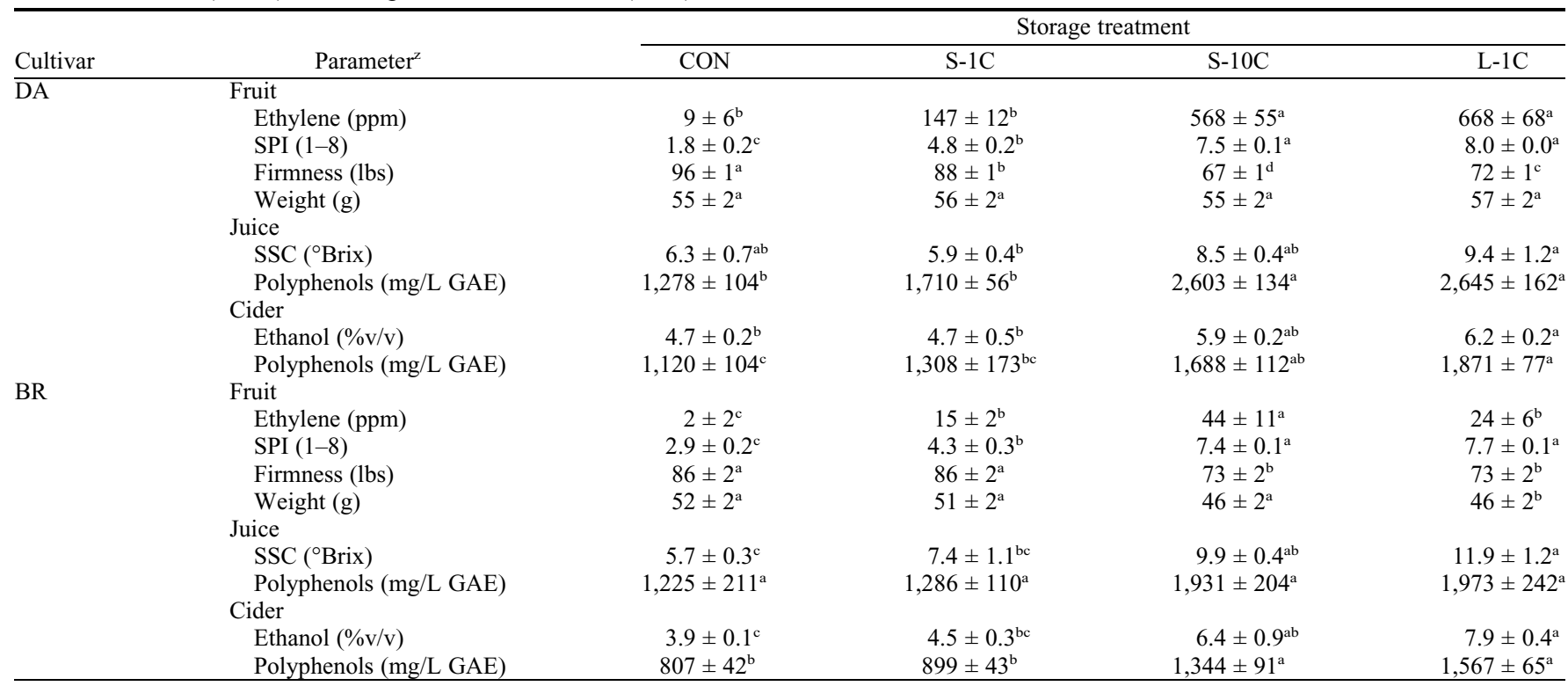

${ }^{\mathrm{z}}$ Values are represented as mean $\pm \mathrm{SE}$ for 40 samples for fruit and four samples for juice and cider. Statistical differences are represented by superscripts and are only considered within each cultivar.

$\mathrm{SPI}=$ starch pattern iodine index; $\mathrm{SSC}=$ soluble solid content; $\mathrm{GAE}=$ gallic acid equivalent.

Rouge' ciders (Supplemental Tables 2, 3, and 6), but it did increase with harvest maturity in the 2016 'GoldRush' and 'Dabinett' ciders (Supplemental Tables 4 and 5).

The effect of varying harvest maturities on the concentrations of individual polyphenols was largely inconsistent in 2015 and 2016 among cultivars. The 2015 'York' ciders had the lowest concentrations of CAT, EPI, PCB1, PCB5, and QUE in the H2 treatment (Supplemental Table 2), whereas 2015 'Dabinett' ciders had the lowest concentrations of EPI, PCB2, PCB5, PCC1, CA2, and CLA (Supplemental Table 3 ) in the $\mathrm{H} 3$ treatments.

The 2016 'GoldRush' ciders had significantly greater concentrations of CAT, EPI, $\mathrm{PCB} 1, \mathrm{PCB} 2, \mathrm{PCB} 5, \mathrm{PCC} 1$, and $\mathrm{CA} 2$ in the H3 treatment (Supplemental Table 4). Individual polyphenol concentrations for 'Dabinett' and 'Binet Rouge' ciders did not vary among treatments for any of the 10 polyphenols measured (Supplemental Tables 5 and 6).

Effects of fruit storage conditions on fruit, juice, and cider. Storage of fruit in varying conditions significantly affected many fruit and juice quality parameters in both harvest years (Table 2). Increased storage times and temperatures resulted in significant decreases in fruit firmness and significant increases in SPI values and ethylene concentration.

SSC increased with storage time and temperature in juice from all cultivars from both harvest years. Juice total polyphenol content also increased significantly with storage time and temperature, except in 'Binet Rouge' juices in 2016, although a trend of increasing means was observed. Although some differences existed, $\mathrm{pH}, \mathrm{TA}$, and PAN did not exhibit consistent trends resulting from the storage treatments (Supplemental Tables 7-11).
Cider $\mathrm{pH}$ was largely unaffected by the storage treatments, and in 2015, 'York' and 'Dabinett' cider TA did not differ as a result of the treatments (Supplemental Tables 7 and 8). However, in 2016, there was a general decrease in TA with increased storage time and temperature in the 'GoldRush', 'Dabinett', and 'Binet Rouge' ciders.

The 2015 'York' and 'Dabinett' ciders did not differ significantly in ethanol concentration among treatments (Supplemental Tables 7 and 8). However, the 2016 'GoldRush', 'Dabinett', and 'Binet Rouge' ciders increased in ethanol concentration as storage time and temperature of fruit increased (Supplemental Tables 9-11).

In 2016, total polyphenols in cider increased with storage time and temperature for 'Dabinett' and 'Binet Rouge' ciders (Fig. 1). There was no significant change in total polyphenol concentration in 'York' and 'Dabinett' ciders in 2015 or in 'GoldRush' ciders in 2016.

The 2015 'York' and 'Dabinett' ciders exhibited no differences in individual polyphenol concentrations as a result of the fruit storage treatments (Supplemental Tables 7 and 8). In 2016, however, several individual polyphenols in 'Dabinett' and 'Binet Rouge' differed among the storage treatments (Fig. 2).

For both 'Dabinett' and 'Binet Rouge' ciders, CAT, EPI, PCB1, PCB2, PCB5, PCC1, CA2, and CLA tended to increase with increased storage time and temperature (Fig. 2). The flavanols represented a greater percentage of individual polyphenols with increased fruit storage time and temperature in the 2016 'Dabinett' and 'Binet Rouge' ciders. Flavanols in 2016 'Dabinett' ciders were $\approx 59.3 \%$ of polyphenols measured in the harvest treatment, $64.1 \%$ in the $\mathrm{S}-1 \mathrm{C}$ treat- ment, $66.6 \%$ in the S-10C treatment, and $68.6 \%$ in the $\mathrm{L}-1 \mathrm{C}$ treatment. Flavanols in the 2016 'Binet Rouge' ciders constituted $\approx 18.5 \%$ of the individual polyphenols measured in the control treatment, $23.6 \%$ in the S$1 \mathrm{C}$ treatment, $43.4 \%$ in the S-10C treatment, and $39.1 \%$ in the $\mathrm{L}-1 \mathrm{C}$ treatment.

In 'GoldRush' ciders, PCB1 was at its greatest concentration in the $\mathrm{S}-10 \mathrm{C}$ treatment and at its least in the L-1C treatment (Supplemental Table 9). None of the other polyphenols measured exhibited statistically significant differences among the treatments.

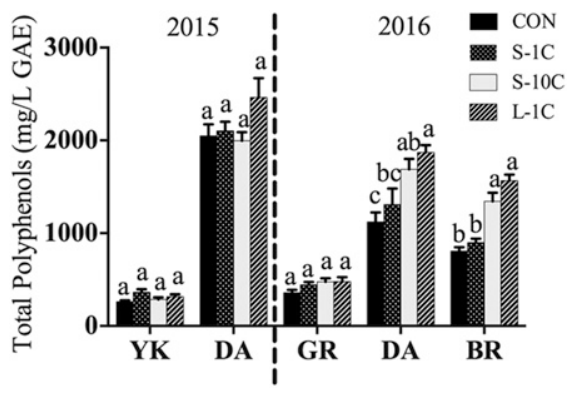

Fig. 1. Total polyphenol concentrations in ciders measured by the Folin-Ciocalteu assay. Error bars represent SE for four biological replicates. Common letters indicate no significant difference $(P<0.05)$ among treatments within a single cultivar in a single harvest year. Cultivars analyzed in 2015 include 'York' (YK) and 'Dabinett' (DA); cultivars analyzed in 2016 include 'GoldRush' (GR), 'Dabinett', and 'Binet Rouge' (BR). Treatments include a control (CON), short-term storage at $1{ }^{\circ} \mathrm{C}(\mathrm{S}-1 \mathrm{C})$, short-term storage at $10{ }^{\circ} \mathrm{C}$ (S-10C), and longterm at $1{ }^{\circ} \mathrm{C}(\mathrm{L}-1 \mathrm{C})$. Comparisons are not made between cultivars and harvest years. 

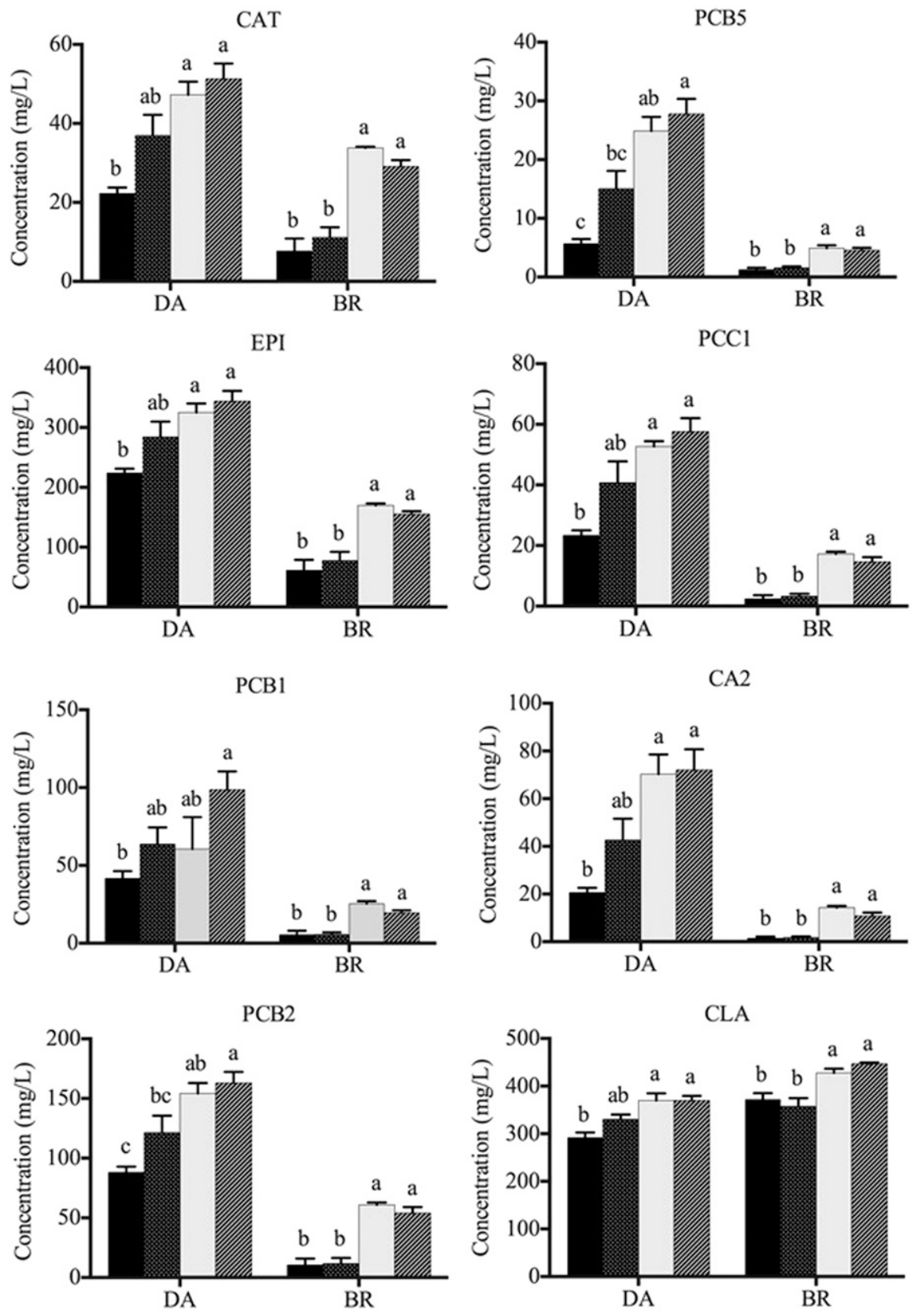

Fig. 2. Individual polyphenols (+)-catechin (CAT), (-)-epicatechin (EPI), procyanidin B1 (PCB1), procyanidin $\mathrm{B} 2$ (PCB2), procyanidin $\mathrm{B} 5$ (PCB5), procyanidin $\mathrm{C} 1$ (PCC1), cinnamtannin $\mathrm{A} 2$ (CA2), and chlorogenic acid (CLA) as measured by UPLC/MS analysis for 'Dabinett' (DA) and 'Binet Rouge' (BR) ciders in Harvest Year 2016. Error bars are represented as SE for four biological replicates. Common letters indicate no significant difference $(P<0.05)$ among treatments within a single cultivar in a single harvest year. Treatments include a control $(\mathrm{CON})$ plus storage of apples for a short-term period at $1{ }^{\circ} \mathrm{C}(\mathrm{S}-1 \mathrm{C})$, a short-term period at $10{ }^{\circ} \mathrm{C}(\mathrm{S}-10 \mathrm{C})$, and 4 months at $1{ }^{\circ} \mathrm{C}(\mathrm{L}-1 \mathrm{C})$.

\section{Discussion}

In general, later harvest dates resulted in increased internal ethylene concentration in the fruit, fruit softening, increases in fruit weight, and decreases in starch content. However, harvest date had inconsistent effects on juice and cider chemistry across cultivars and harvest years, which has been observed previously (Alberti et al., 2016; Laaksonen et al., 2017). It would be expected that more mature fruit would result in a greater SSC in juice and a greater ethanol content in cider, but in our study, differences predict solely on the maturity of the fruit. Therefore, maturity at harvest does not seem to be a reliable mechanism for manipulating the concentration of polyphenols.

The fruit storage treatments also affected fruit, juice, and cider characteristics. Increased time and temperature of fruit storage increased fruit ripening during storage and resulted in softer fruit, increased SSC in juice, and decreased TA in juice. A treatment-based increase of total polyphenols in juice did not always correlated directly with an increase of total polyphenols in cider, and the concentration of total polyphenols decreased from juice to cider. Total polyphenol concentration in juice also increased with fruit storage time and temperature, but this could also be the result of concentration by dehydration, as fruit weight was also decreasing with increased storage time and temperature. These results contradict those from a study by Laaksonen et al. (2017), in which increased fruit ripening in storage resulted in lower concentrations of polyphenols for 'Antei', 'Melba', and 'Orlovski sinap'. It is certainly possible that different cultivars may respond differently to these treatments.

It is possible that the polyphenols increased by ethylene action, as mentioned in previous studies (Leja et al., 2003; Napolitano et al., 2004). Greater ethylene concentrations in fruit, as observed in the S-10C and L-1C treatments, were observed to correlate generally with an increase of total polyphenols in the 2015 'Dabinett' and 'Brown Snout' juices and the 2016 'GoldRush', 'Dabinett', and 'Binet Rouge' juices. If this was to be the mechanism by which polyphenol increases could occur, then applications of exogenous ethylene or at least containment of the gas could be used to manipulate polyphenol expression. Although these ethylene action hypotheses have been made in previous work (Leja et al., 2003; Napolitano et al., 2004), other research by Defilippi et al. (2004) using strict ethylene synthesis control and exposure methods has suggested that ethylene is likely not responsible for an increase in polyphenols during storage. Furthermore, the correlation of ethylene concentration and total polyphenols in cider only applies to the 2016 'Dabinett' and 'Binet Rouge' ciders, with observed concentration increases in the flavanols and CLA. However, the flavanols in both cases had relatively greater concentration increases compared with CLA and represented a greater fraction of the overall polyphenol composition in the S-10C and L-1C treatments. This was most noticeable in the 2016 'Binet Rouge' ciders, in which CLA represented $81.5 \%$ and $76.4 \%$ of the individual polyphenols measured in the control and S$1 \mathrm{C}$ treatments, respectively, and $56.6 \%$ and $60.9 \%$ in the S-10C and L-1C treatments, respectively. Ultimately, an increase in flavanol concentrations, compared with other polyphenol classes, has a greater potential to contribute to the organoleptic qualities of bitterness and astringency desired by cider makers. 
Although the S-10C and L-1C storage treatments increased polyphenol and flavanol concentrations in 2016 'Dabinett' and 'Binet Rouge' ciders, it is unclear to what extent these variations in concentration would be detectable organoleptically. Increases in flavanol monomers such as CAT and EPI would result in more bitter characteristics, whereas increases in oligomers and polymers would result in more astringent characteristics (Peleg et al., 1999). However, the sensory thresholds of each compound are largely unknown, especially in a complex matrix like cider. For example, CAT in water has been estimated to have a sensory threshold of $46.1 \mathrm{mg} / \mathrm{L}$, which would be greater than most of the concentrations measured in this study, but a mixture of CAT, trimers, and tetramers in water has been reported to have a sensory threshold of only $3.6 \mathrm{mg} / \mathrm{L}$ (Delcour et al., 1984). Therefore, a mixture of different-size polyphenols may exhibit much lower sensory detection thresholds and thus sensory impact than a solution of monomers alone.

It is also important to consider that this fruit also decreased in weight and fruit firmness during storage, which could decrease yield and crushing efficiency during cider production, potentially affecting process economics negatively. Furthermore, variations in fruit ethylene concentration are also likely to result in differences in volatile aroma compositions and concentrations in juice and cider (Defilippi et al., 2004). Although interesting, the effect of storage on volatile aromas is beyond the scope of our study. Last, it is important to acknowledge that variations in production locations and systems could influence the results of similar experiments performed under different conditions, and more research would be required to draw broader conclusions across regions and systems.

\section{Conclusion}

Although the sensory character of cider is complex and dependent on concentrations of several classes of compounds, the flavanol class of polyphenols is especially important to cider quality because it imparts bitterness and astringency characteristics provided by traditional cider apples. Our research indicates that for cultivars Dabinett and Binet Rouge, increases in fruit storage time and temperature may provide a mechanism by which to increase flavanol concentrations in cider made from this fruit. This information can help maximize the effect of cider apples that are in increasing demand while the fruit is in short supply in the United States.

\section{Literature Cited}

Alberti, A., T.P. Machado dos Santos, A.A. Ferreira Zielinski, C.M. Eleutério dos Santos, C.M. Braga, I.M. Demiate, and A. Nogueira. 2016. Impact on chemical profile in apple juice and cider made from unripe, ripe and senescent dessert varieties. Lebensm. Wiss. Technol. 65:436-443.

Alonso-Salces, R.M., C. Herrero, A. Barranco, L.A. Berrueta, B. Gallo, and F. Vicente. 2005. Classification of apple fruits according to their maturity state by the pattern recognition analysis of their polyphenolic compositions. Food Chem. 93:113-123.

Barker, B.T.P. and J. Ettle. 1910. Report on the work of the National Fruit and Cider Institute, 1903-1910. National Fruit and Cider Institute, Long Ashton, UK.

Bell, S.-J. and P.A. Henschke. 2005. Implications of nitrogen nutrition for grapes, fermentation and wine. Austral. J. Grape Wine Res. 11:242295.

Blanpied, G.D. and K.J. Silsby. 1992. Predicting harvest date windows for apples. 1 Nov. 2018. $<$ https://ecommons.cornell.edu/bitstream/handle/ 1813/3299/Predicting\%20Harvest $\% 20$ Date \% 20Window $\% 20$ for $\% 20$ Apples.pdf? sequence $=$ 2\&isAllowed $=\mathrm{y}>$

Brager, D. and M. Crompton. 2017. U.S. cider trends: Increasing your odds of success by evaluating marketplace dynamics. 1 Nov. 2018. <https://ciderassociation.org/cider-trendsin-the-u-s/ $>$.

Burda, S., W. Oleszek, and C.Y. Lee. 1990. Phenolic compounds and their changes in apples during maturation and cold storage. J. Agr. Food Chem. 38:945-948.

Defilippi, B.G., A.M. Dandekar, and A.A. Kader. 2004. Impact of suppression of ethylene action or biosynthesis on flavor metabolites in apple (Malus domestica Borkh) fruits. J. Agr. Food Chem. 52:5694-5701.

Delcour, J.A., M.M. Vandenberghe, P.F. Corten, and P. Dondeyne. 1984. Flavor thresholds of polyphenolics in water. Amer. J. Enol. Viticult. 35:134-136.

Dukes, B.C. and C.E. Butzke. 1998. Rapid determination of primary amino acids in grape juice using an o-phthaldialdehyde/ $\mathrm{N}$-acetylL-cysteine spectrophotometric assay. Amer. J. Enol. Viticult. 49:125-134.

Guyot, S., N. Marnet, D. Laraba, P. Sanoner, and J.-F. Drilleau. 1998. Reversed-phase HPLC following thiolysis for quantitative estimation and characterization of the four main classes of phenolic compounds in different tissue zones of a French cider apple variety (Malus domestica var. Kermerrien). J. Agr. Food Chem. 46:16981705.

Guyot, S., N. Marnet, P. Sanoner, and J.-F Drilleau. 2003. Variability of the polyphenolic composition of cider apple (Malus domestica) fruits and juices. J. Agr. Food Chem. 51:6240 6247.

Iland, P. 2004. Chemical analysis of grapes and wine. Patrick Iland Wine Promotions PTYLTD, Athelstone, SA, Australia.

Laaksonen, O., R. Kuldjärv, T. Paalme, M. Virkki, and B. Yang. 2017. Impact of apple cultivar, ripening stage, fermentation type and yeast strain on phenolic composition of apple ciders. Food Chem. 233:29-37.

Lea, A.G.H. and J.R. Piggott. 2012. Fermented beverage production. Springer, New York, NY.

Leja, M., A. Mareczek, and J. Ben. 2003. Antioxidant properties of two apple cultivars during long-term storage. Food Chem. 80:303-307.

Lu, Y. and L.Y. Foo. 1997. Identification and quantification of major polyphenols in apple pomace. Food Chem. 59:187-194.

Martin, M., O.I. Padilla-Zakour, and C. Gerling. 2017. Tannin additions to improve the quality of hard cider made from dessert apples. New York State Hort. Soc. 25:25-28.

Merwin, I.A., S. Valois, and O.I. Padilla-Zakour. 2008. Cider apples and cider-making techniques in Europe and North America. Hort Rev. 34:365-413.
Miles, C. and J. King. 2014. Yield, labor, and fruit and juice quality characteristics of machine and hand-harvested 'Brown Snout' specialty cider apple. HortTechnology 24:519-526.

Mosel, H.-D. and K. Herrmann. 1974. Changes in catechins and hydroxycinnamic acid derivatives during development of apples and pears. J. Agr. Food Chem. 25:251-256.

Murata, M., M. Tsurutani, M. Tomita, S. Homma, and K. Kaneko. 1995. Relationship between apple ripening and browning: Changes in polyphenol content and polyphenol oxidase. J. Agr. Food Chem. 43:1115-1121.

Napolitano, A., A. Cascone, G. Graziani, R. Ferracane, L. Scalfi, C. Di Vaio, A. Ritieni, and V. Fogliano. 2004. Influence of variety and storage on the polyphenol composition of apple flesh. J. Agr. Food Chem. 52:6526-6531.

Nicolas, J.J., F.C. Richard-Forget, P.M. Goupy, M.-J. Amiot, and S.Y. Aubert. 1994. Enzymatic browning reactions in apple and apple products. Crit. Rev. Food Sci. Nutr. 34:109-157.

Peleg, H., K. Gacon, P. Schlich, and A.C. Noble. 1999. Bitterness and astringency of flavan-3-ol monomers, dimers and trimers. J. Sci. Food Agr. 79:1123-1128.

Petrillo, N. 2016. Bitter but sweet: Sales of hard cider have plateaued following years of unprecedented growth. IBISWorld Industry Report OD5335.

Renard, C.M.G.C., N. Dupont, and P. Guillermin. 2007. Concentrations and characteristics of procyanidins and other phenolics in apples during fruit growth. Phytochemistry 68:11281138 .

Sanoner, P., S. Guyot, N. Marnet, D. Molle, and J.-F. Drilleau. 1999. Polyphenol profiles of French cider apple varieties (Malus domestica sp.). J. Agr. Food Chem. 47:4847-4853.

Spanos, G.A. and R.E. Wrolstad. 1992. Phenolics of apple, pear, and white grape juices and their changes with processing and storage: A review. J. Agr. Food Chem. 40:1478-1487.

Thompson-Witrick, K.A., K.M. Goodrich, A.P. Neilson, E.K. Hurley, G.M. Peck, and A.C. Stewart. 2014. Characterization of the polyphenol composition of 20 cultivars of cider, processing, and dessert apples (Malus $\times$ domestica Borkh.) grown in Virginia. J. Agr. Food Chem. 62:10181-10191.

Valois, S., I.A. Merwin, and O.I. Padilla-Zakour. 2006. Characterization of fermented cider apple cultivars grown in upstate New York. J. Amer. Pomol. Soc. 60:113-128.

van der Sluis, A.A., M. Dekker, A. de Jager, and W.M.F. Jongen. 2001. Activity and concentration of polyphenolic antioxidants in apple: Effect of cultivar, harvest year, and storage conditions. J. Agr. Food Chem. 49:3606-3613.

Verdu, C.F., N. Childebrand, N. Marnet, G. Lebail, F. Dupuis, F. Laurens, D. Guilet, and S. Guyot. 2014. Polyphenol variability in the fruits and juices of a cider apple progeny. J. Agr. Food Chem. 94:1305-1314.

Vidal, S., L. Francis, S. Guyot, N. Marnet, M. Kwiatkowski, R. Gawel, V. Cheynier, and E.J. Waters. 2003. The mouth-feel properties of grape and apple proanthocyanidins in a winelike medium. J. Agr. Food Chem. 83:564-573.

Vrhovsek, U., A. Rigo, D. Tonon, and F. Mattivi. 2004. Quantitation of polyphenols in different apple varieties. J. Agr. Food Chem. 52:65326538 .

Waterhouse, A.L. 2002. Determination of total phenolics. Curr. Prot. Food Anal. Chem. 6: I1.1.1-I1.1.8. 
Supplemental Table 1. Retention times, molecular weights, and SIR channels for polyphenols.

\begin{tabular}{lccc}
\hline Compound & Retention time $(\mathrm{min})$ & Molecular weight $(\mathrm{g} / \mathrm{mol})$ & SIR $(\mathrm{m} / \mathrm{z})$ \\
\hline CAT & 2.892 & 290.092 & 289.09 \\
EPI & 3.614 & 290.092 & 289.09 \\
PC B1 & 2.476 & 578.07 & 577.13 \\
PC B2 & 3.363 & 378.04 & 577.13 \\
PC B5 & 4.762 & 578.136 & 577.13 \\
PC C1 & 3.889 & 866.218 & 865.21 \\
CA2 & 4.047 & 1154.808 & 576.4 \\
QUE & 6.673 & 302.23 & 301.01 \\
PHL & 7.440 & 274.26 & 273.05 \\
CLA & 2.992 & 354.31 & 353.06 \\
\hline
\end{tabular}

Supplemental Table 2. Summary of 2015 York fruit, juice, and cider maturity data.

\begin{tabular}{|c|c|c|c|}
\hline \multirow[b]{2}{*}{ Parameter } & \multicolumn{3}{|c|}{ Harvest treatment } \\
\hline & H1 & $\mathrm{H} 2$ & $\mathrm{H} 3$ \\
\hline \multicolumn{4}{|l|}{ Fruit } \\
\hline Ethylene (ppm) & $1.71 \pm 0.88^{\mathrm{b}}$ & $8.08 \pm 8.07^{\mathrm{ab}}$ & $11.73 \pm 3.66^{\mathrm{a}}$ \\
\hline SPI $(1-8)$ & $1.2 \pm 0.1^{\mathrm{b}}$ & $1.9 \pm 0.2^{\mathrm{a}}$ & $2.3 \pm 0.2^{\mathrm{a}}$ \\
\hline Firmness (lbs) & $99.2 \pm 1.3^{\mathrm{a}}$ & $86.7 \pm 1.3^{\mathrm{b}}$ & $87.2 \pm 1.3^{\mathrm{b}}$ \\
\hline Weight $(\mathrm{g})$ & $148.7 \pm 5.2^{\mathrm{b}}$ & $179.9 \pm 6.6^{\mathrm{a}}$ & $185.3 \pm 6.8^{\mathrm{a}}$ \\
\hline Red color $(0-100 \%)$ & $45.9 \pm 3.5^{\mathrm{b}}$ & $75.3 \pm 2.6^{\mathrm{a}}$ & $81.3 \pm 2.1^{\mathrm{a}}$ \\
\hline \multicolumn{4}{|l|}{ Juice } \\
\hline $\operatorname{SSC}\left({ }^{\circ}\right.$ Brix $)$ & $9.4 \pm 0.5^{\mathrm{ab}}$ & $7.9 \pm 0.3^{b}$ & $9.5 \pm 0.2^{\mathrm{a}}$ \\
\hline $\mathrm{pH}$ & $3.5 \pm 0.1^{\mathrm{a}}$ & $3.5 \pm 0.1^{\mathrm{a}}$ & $3.4 \pm 0.1^{\mathrm{a}}$ \\
\hline TA (g/L malic acid) & $5.0 \pm 0.1^{\mathrm{a}}$ & $5.2 \pm 0.2^{\mathrm{a}}$ & $4.9 \pm 0.4^{\mathrm{a}}$ \\
\hline SSC:TA & $1.9 \pm 0.1^{\mathrm{a}}$ & $1.5 \pm 0.1^{\mathrm{a}}$ & $2.0 \pm 0.2^{\mathrm{a}}$ \\
\hline PAN & $44 \pm 2^{\mathrm{a}}$ & $50 \pm 3^{\mathrm{a}}$ & $38 \pm 9^{\mathrm{a}}$ \\
\hline Polyphenols (mg/L GAE) & $363 \pm 9^{b}$ & $424 \pm 4^{\mathrm{a}}$ & $292 \pm 19^{c}$ \\
\hline \multicolumn{4}{|l|}{ Cider } \\
\hline $\mathrm{pH}$ & $3.6 \pm 0.0^{\mathrm{a}}$ & $3.6 \pm 0.0^{\mathrm{a}}$ & $3.6 \pm 0.1^{\mathrm{a}}$ \\
\hline TA ( $\mathrm{g} / \mathrm{mL}$ malic acid) & $4.7 \pm 0.8^{\mathrm{a}}$ & $4.7 \pm 0.8^{\mathrm{a}}$ & $4.7 \pm 0.8^{\mathrm{a}}$ \\
\hline Ethanol (\%v/v) & $5.9 \pm 0.3^{\mathrm{a}}$ & $6.6 \pm 0.1^{\mathrm{a}}$ & $6.7 \pm 0.3^{\mathrm{a}}$ \\
\hline Polyphenols (mg/L GAE) & $226 \pm 13^{a}$ & $192 \pm 10^{\mathrm{a}}$ & $244 \pm 16^{\mathrm{a}}$ \\
\hline \multicolumn{4}{|l|}{ Individual Polyphenols } \\
\hline CAT & $13.7 \pm 2.0^{\mathrm{ab}}$ & $8.4 \pm 1.2^{\mathrm{b}}$ & $14.9 \pm 1.4^{\mathrm{a}}$ \\
\hline EPI & $44.7 \pm 2.1^{\mathrm{a}}$ & $34.0 \pm 4.6^{\mathrm{b}}$ & $45.2 \pm 4.6^{\mathrm{a}}$ \\
\hline PCB1 & $24.5 \pm 3.5^{\mathrm{a}}$ & $13.3 \pm 2.5^{\mathrm{a}}$ & $22.0 \pm 3.5^{\mathrm{a}}$ \\
\hline PCB2 & $39.5 \pm 3.7^{\mathrm{a}}$ & $21.5 \pm 3.4^{\mathrm{b}}$ & $36.1 \pm 3.9^{\mathrm{ab}}$ \\
\hline PCB5 & $2.82 \pm 0.26^{\mathrm{a}}$ & $1.82 \pm 0.20^{\mathrm{b}}$ & $2.87 \pm 0.29^{\mathrm{a}}$ \\
\hline $\mathrm{PCC} 1$ & $7.83 \pm 1.33^{\mathrm{a}}$ & $3.39 \pm 0.87^{\mathrm{a}}$ & $7.23 \pm 1.47^{\mathrm{a}}$ \\
\hline CA2 & $3.05 \pm 0.44^{\mathrm{a}}$ & $2.04 \pm 0.23^{\mathrm{a}}$ & $7.38 \pm 3.92^{\mathrm{a}}$ \\
\hline QUE & $2.84 \pm 0.30^{\mathrm{a}}$ & $1.40 \pm 0.19^{\mathrm{b}}$ & $2.38 \pm 0.19^{\mathrm{a}}$ \\
\hline PHL & $0.62 \pm 0.11^{\mathrm{a}}$ & $0.09 \pm 0.09^{\mathrm{b}}$ & $0.32 \pm 0.12^{\mathrm{ab}}$ \\
\hline CLA & $136 \pm 3^{\mathrm{a}}$ & $128 \pm 7^{\mathrm{a}}$ & $138 \pm 5^{\mathrm{a}}$ \\
\hline
\end{tabular}


Supplemental Table 3. Summary of 2015 Dabinett fruit, juice, and cider maturity data.

\begin{tabular}{|c|c|c|c|}
\hline \multirow[b]{2}{*}{ Parameter } & \multicolumn{3}{|c|}{ Harvest treatment } \\
\hline & H1 & $\mathrm{H} 2$ & H3 \\
\hline \multicolumn{4}{|l|}{ Fruit } \\
\hline Ethylene (ppm) & $0.07 \pm 0.07^{\mathrm{b}}$ & $5.97 \pm 5.59^{\mathrm{ab}}$ & $22.96 \pm 4.03^{\mathrm{a}}$ \\
\hline SPI $(1-8)$ & $1.3 \pm 0.1^{\mathrm{b}}$ & $2.2 \pm 0.1^{\mathrm{a}}$ & $2.6 \pm 0.2^{\mathrm{a}}$ \\
\hline Firmness (lbs) & $129.0 \pm 1.3^{\mathrm{a}}$ & $115.2 \pm 1.8^{\mathrm{b}}$ & $118.3 \pm 1.8^{\mathrm{b}}$ \\
\hline Weight $(\mathrm{g})$ & $49.2 \pm 2.0^{\mathrm{b}}$ & $59.93 \pm 2.6^{\mathrm{a}}$ & $57.2 \pm 2.3^{\mathrm{a}}$ \\
\hline Red color $(0-100 \%)$ & $30.5 \pm 2.9^{b}$ & $57.6 \pm 3.2^{\mathrm{a}}$ & $57.3 \pm 3.8^{\mathrm{a}}$ \\
\hline \multicolumn{4}{|l|}{ Juice } \\
\hline $\operatorname{SSC}\left({ }^{\circ}\right.$ Brix $)$ & $11.1 \pm 0.4^{\mathrm{a}}$ & $11.3 \pm 0.0^{\mathrm{a}}$ & $10.6 \pm 0.4^{\mathrm{a}}$ \\
\hline $\mathrm{pH}$ & $4.5 \pm 0.1^{\mathrm{a}}$ & $4.4 \pm 0.1^{\mathrm{a}}$ & $4.3 \pm 0.2^{\mathrm{a}}$ \\
\hline TA (g/L malic acid) & $1.3 \pm 0.1^{\mathrm{a}}$ & $1.3 \pm 0.1^{\mathrm{a}}$ & $1.3 \pm 0.1^{\mathrm{a}}$ \\
\hline SSC:TA & $8.7 \pm 0.8^{\mathrm{a}}$ & $8.9 \pm 0.4^{\mathrm{a}}$ & $8.6 \pm 0.8^{\mathrm{a}}$ \\
\hline PAN & $47 \pm 4^{\mathrm{a}}$ & $31 \pm 5^{\mathrm{a}}$ & $36 \pm 9^{\mathrm{a}}$ \\
\hline Polyphenols (mg/L GAE) & $1718 \pm 141^{\mathrm{a}}$ & $1420 \pm 125^{\mathrm{a}}$ & $1190 \pm 161^{\mathrm{a}}$ \\
\hline \multicolumn{4}{|l|}{ Cider } \\
\hline $\mathrm{pH}$ & $4.2 \pm 0.0^{\mathrm{a}}$ & $4.2 \pm 0.0^{\mathrm{a}}$ & $4.2 \pm 0.0^{\mathrm{a}}$ \\
\hline TA (g/mL malic acid) & $3.7 \pm 0.4^{\mathrm{a}}$ & $6.4 \pm 1.4^{\mathrm{a}}$ & $5.3 \pm 0.4^{\mathrm{a}}$ \\
\hline Ethanol $(\% \mathrm{v} / \mathrm{v})$ & $6.7 \pm 0.3^{\mathrm{a}}$ & $7.2 \pm 0.1^{\mathrm{a}}$ & $7.3 \pm 0.4^{\mathrm{a}}$ \\
\hline Polyphenols (mg/L GAE) & $1594 \pm 126^{\mathrm{a}}$ & $1654 \pm 69^{\mathrm{a}}$ & $1294 \pm 111^{\mathrm{a}}$ \\
\hline \multicolumn{4}{|l|}{ Individual Polyphenols } \\
\hline CAT & $35.9 \pm 2.4^{\mathrm{a}}$ & $36.7 \pm 5.4^{\mathrm{a}}$ & $19.8 \pm 5.6^{\mathrm{a}}$ \\
\hline EPI & $204 \pm 9^{\mathrm{ab}}$ & $215 \pm 15^{\mathrm{a}}$ & $142 \pm 23^{b}$ \\
\hline PCB1 & $119 \pm 10^{\mathrm{a}}$ & $132 \pm 21^{\mathrm{a}}$ & $59 \pm 25^{\mathrm{a}}$ \\
\hline PCB2 & $167 \pm 11^{\mathrm{ab}}$ & $189 \pm 18^{\mathrm{a}}$ & $94 \pm 27^{b}$ \\
\hline PCB5 & $19.0 \pm 2.7^{\mathrm{ab}}$ & $24.0 \pm 4.3^{\mathrm{a}}$ & $6.7 \pm 4.2^{\mathrm{b}}$ \\
\hline PCC1 & $138 \pm 12^{\mathrm{ab}}$ & $162 \pm 25^{\mathrm{a}}$ & $55 \pm 32^{\mathrm{b}}$ \\
\hline $\mathrm{CA} 2$ & $82 \pm 10^{\mathrm{ab}}$ & $102 \pm 21^{\mathrm{a}}$ & $29 \pm 21^{\mathrm{b}}$ \\
\hline QUE & $1.79 \pm 0.17^{\mathrm{a}}$ & $2.32 \pm 0.72^{\mathrm{a}}$ & $0.88 \pm 0.06^{\mathrm{a}}$ \\
\hline PHL & $2.04 \pm 1.20^{\mathrm{a}}$ & $2.60 \pm 0.94^{\mathrm{a}}$ & $0.27 \pm 0.11^{\mathrm{a}}$ \\
\hline CLA & $174 \pm 3^{\mathrm{a}}$ & $178 \pm 1^{\mathrm{a}}$ & $153 \pm 6^{\mathrm{b}}$ \\
\hline
\end{tabular}

Supplemental Table 4. Summary of 2016 GoldRush fruit, juice, and cider maturity data.

\begin{tabular}{|c|c|c|c|}
\hline \multirow[b]{2}{*}{ Parameter } & \multicolumn{3}{|c|}{ Harvest treatment } \\
\hline & H1 & $\mathrm{H} 2$ & $\mathrm{H} 3$ \\
\hline \multicolumn{4}{|l|}{ Fruit } \\
\hline Ethylene (ppm) & $0.10 \pm 0.01^{\mathrm{c}}$ & $0.25 \pm 0.02^{\mathrm{b}}$ & $0.69 \pm 0.08^{\mathrm{a}}$ \\
\hline SPI $(1-8)$ & $2.2 \pm 0.2^{\mathrm{c}}$ & $3.7 \pm 0.1^{\mathrm{b}}$ & $5.0 \pm 0.2^{\mathrm{a}}$ \\
\hline Firmness (lbs) & $83.5 \pm 0.9^{\mathrm{a}}$ & $78.7 \pm 0.9^{b}$ & $77.7 \pm 0.9^{b}$ \\
\hline Weight $(\mathrm{g})$ & $141.4 \pm 4.5^{\mathrm{a}}$ & $147.3 \pm 4.4^{\mathrm{a}}$ & $144.1 \pm 5.3^{\mathrm{a}}$ \\
\hline Green background color (1-4) & $2.2 \pm 0.1^{\mathrm{a}}$ & $1.9 \pm 0.1^{\mathrm{a}}$ & $1.4 \pm 0.1^{\mathrm{b}}$ \\
\hline \multicolumn{4}{|l|}{ Juice } \\
\hline $\mathrm{SSC}\left({ }^{\circ} \mathrm{Brix}\right)$ & $6.5 \pm 0.6^{\mathrm{b}}$ & $8.7 \pm 0.1^{\mathrm{b}}$ & $12.4 \pm 0.9^{\mathrm{a}}$ \\
\hline $\mathrm{pH}$ & $3.5 \pm 0.0^{\mathrm{a}}$ & $3.4 \pm 0.0^{\mathrm{ab}}$ & $3.4 \pm 0.0^{\mathrm{b}}$ \\
\hline TA (g/L malic acid) & $8.6 \pm 0.3^{\mathrm{a}}$ & $10.4 \pm 1.6^{\mathrm{a}}$ & $12.2 \pm 1.1^{\mathrm{a}}$ \\
\hline SSC:TA & $0.8 \pm 0.0^{\mathrm{a}}$ & $0.9 \pm 0.2^{\mathrm{a}}$ & $1.1 \pm 0.2^{\mathrm{a}}$ \\
\hline PAN & $25 \pm 6^{\mathrm{b}}$ & $33 \pm 5^{\mathrm{b}}$ & $74 \pm 4^{\mathrm{a}}$ \\
\hline Polyphenols (mg/L GAE) & $516 \pm 17^{b}$ & $575 \pm 28^{\mathrm{b}}$ & $670 \pm 17^{\mathrm{a}}$ \\
\hline \multicolumn{4}{|l|}{ Cider } \\
\hline $\mathrm{pH}$ & $3.5 \pm 0.0^{\mathrm{a}}$ & $3.5 \pm 0.0^{\mathrm{a}}$ & $3.5 \pm 0.0^{\mathrm{a}}$ \\
\hline TA (g/mL malic acid) & $9.2 \pm 1.4^{\mathrm{a}}$ & $10.6 \pm 0.1^{\mathrm{a}}$ & $11.0 \pm 0.5^{\mathrm{a}}$ \\
\hline Ethanol $(\% \mathrm{v} / \mathrm{v})$ & $5.2 \pm 0.2^{\mathrm{b}}$ & $7.5 \pm 0.4^{\mathrm{a}}$ & $7.7 \pm 0.4^{\mathrm{a}}$ \\
\hline Polyphenols (mg/L GAE) & $439 \pm 11^{\mathrm{a}}$ & $454 \pm 27^{\mathrm{a}}$ & $520 \pm 21^{\mathrm{a}}$ \\
\hline \multicolumn{4}{|l|}{ Individual Polyphenols } \\
\hline CAT & $3.4 \pm 0.4^{\mathrm{b}}$ & $4.5 \pm 0.5^{\mathrm{b}}$ & $11.0 \pm 0.4^{\mathrm{a}}$ \\
\hline EPI & $102 \pm 7^{\mathrm{b}}$ & $93 \pm 4^{\mathrm{b}}$ & $144 \pm 3^{\mathrm{a}}$ \\
\hline PCB1 & $9.8 \pm 1.1^{\mathrm{b}}$ & $12.9 \pm 1.8^{\mathrm{b}}$ & $30.5 \pm 1.4^{\mathrm{a}}$ \\
\hline PCB2 & $40.6 \pm 4.0^{\mathrm{b}}$ & $28.3 \pm 2.0^{\mathrm{c}}$ & $68.5 \pm 2.3^{\mathrm{a}}$ \\
\hline PCB5 & $2.88 \pm 0.47^{\mathrm{b}}$ & $2.60 \pm 0.18^{\mathrm{b}}$ & $6.94 \pm 0.36^{\mathrm{a}}$ \\
\hline PCC 1 & $8.9 \pm 1.0^{\mathrm{b}}$ & $5.8 \pm 0.4^{\mathrm{b}}$ & $16.5 \pm 1.1^{\mathrm{a}}$ \\
\hline CA2 & $5.3 \pm 0.8^{\mathrm{b}}$ & $2.8 \pm 0.2^{\mathrm{b}}$ & $10.1 \pm 1.1^{\mathrm{a}}$ \\
\hline QUE & $0 \pm 0^{\mathrm{a}}$ & $0 \pm 0^{\mathrm{a}}$ & $0 \pm 0^{\mathrm{a}}$ \\
\hline PHL & $0 \pm 0^{\mathrm{a}}$ & $0 \pm 0^{\mathrm{a}}$ & $0 \pm 0^{\mathrm{a}}$ \\
\hline CLA & $244 \pm 8^{b}$ & $266 \pm 2^{\mathrm{a}}$ & $281 \pm 4^{\mathrm{a}}$ \\
\hline
\end{tabular}


Supplemental Table 5. Summary of 2016 Dabinett fruit, juice, and cider maturity data.

\begin{tabular}{|c|c|c|c|}
\hline \multirow[b]{2}{*}{ Parameter } & \multicolumn{3}{|c|}{ Harvest treatment } \\
\hline & H1 & $\mathrm{H} 2$ & $\mathrm{H} 3$ \\
\hline \multicolumn{4}{|l|}{ Fruit } \\
\hline Ethylene (ppm) & $0.21 \pm 0.07^{\mathrm{a}}$ & $5.80 \pm 3.94^{\mathrm{a}}$ & $6.61 \pm 4.15^{\mathrm{a}}$ \\
\hline SPI $(1-8)$ & $1.4 \pm 0.1^{\mathrm{b}}$ & $1.8 \pm 0.2^{\mathrm{b}}$ & $2.5 \pm 0.2^{\mathrm{a}}$ \\
\hline Firmness (lbs) & - & $97.4 \pm 1.0^{\mathrm{a}}$ & $89.2 \pm 1.2^{\mathrm{a}}$ \\
\hline Weight $(\mathrm{g})$ & $53.2 \pm 2.1^{\mathrm{b}}$ & $53.7 \pm 2.0^{\mathrm{b}}$ & $66.0 \pm 2.3^{\mathrm{a}}$ \\
\hline Red color $(0-100 \%)$ & $47.7 \pm 3.5^{\mathrm{b}}$ & $59.9 \pm 4.2^{\mathrm{a}}$ & $67.1 \pm 2.8^{\mathrm{a}}$ \\
\hline \multicolumn{4}{|l|}{ Juice } \\
\hline SSC $\left({ }^{\circ}\right.$ Brix $)$ & $9.6 \pm 1.1^{\mathrm{a}}$ & $6.9 \pm 1.1^{\mathrm{a}}$ & $8.7 \pm 0.6^{\mathrm{a}}$ \\
\hline $\mathrm{pH}$ & $4.6 \pm 0.0^{\mathrm{a}}$ & $4.6 \pm 0.0^{\mathrm{a}}$ & $4.6 \pm 0.0^{\mathrm{a}}$ \\
\hline TA ( $\mathrm{g} / \mathrm{L}$ malic acid $)$ & $3.0 \pm 1.4^{\mathrm{a}}$ & $1.3 \pm 0.1^{\mathrm{a}}$ & $3.2 \pm 1.8^{\mathrm{a}}$ \\
\hline SSC:TA & $5.2 \pm 1.6^{\mathrm{a}}$ & $5.6 \pm 1.2^{\mathrm{a}}$ & $5.2 \pm 1.6^{\mathrm{a}}$ \\
\hline PAN & $36 \pm 5^{\mathrm{b}}$ & $78 \pm 16^{\mathrm{a}}$ & $51 \pm 6^{\mathrm{ab}}$ \\
\hline Polyphenols (mg/L GAE) & $1421 \pm 122^{\mathrm{a}}$ & $1306 \pm 53^{\mathrm{a}}$ & $1315 \pm 89^{\mathrm{a}}$ \\
\hline \multicolumn{4}{|l|}{ Cider } \\
\hline pH & $4.3 \pm 0.0^{\mathrm{a}}$ & $4.3 \pm 0.1^{\mathrm{a}}$ & $4.3 \pm 0.1^{\mathrm{a}}$ \\
\hline TA $(\mathrm{g} / \mathrm{mL}$ malic acid $)$ & $2.4 \pm 0.2^{\mathrm{a}}$ & $2.8 \pm 0.4^{\mathrm{a}}$ & $2.9 \pm 0.2^{\mathrm{a}}$ \\
\hline Ethanol $(\% \mathrm{v} / \mathrm{v})$ & $3.7 \pm 0.2^{\mathrm{b}}$ & $4.5 \pm 0.4^{\mathrm{ab}}$ & $5.1 \pm 0.1^{\mathrm{a}}$ \\
\hline Polyphenols (mg/L GAE) & $1164 \pm 68^{\mathrm{a}}$ & $1114 \pm 93^{\mathrm{a}}$ & $1108 \pm 53^{\mathrm{a}}$ \\
\hline \multicolumn{4}{|l|}{ Individual Polyphenols } \\
\hline CAT & $3.67 \pm 0.79^{\mathrm{a}}$ & $3.29 \pm 1.32^{\mathrm{a}}$ & $5.66 \pm 3.07^{\mathrm{a}}$ \\
\hline EPI & $75.6 \pm 15.8^{\mathrm{a}}$ & $80.0 \pm 22.2^{\mathrm{a}}$ & $92.8 \pm 32.9^{\mathrm{a}}$ \\
\hline PCB1 & $9.5 \pm 2.3^{\mathrm{a}}$ & $11.3 \pm 4.3^{\mathrm{a}}$ & $10.8 \pm 5.9^{\mathrm{a}}$ \\
\hline PCB2 & $21.1 \pm 6.5^{\mathrm{a}}$ & $27.4 \pm 11.6^{\mathrm{a}}$ & $25.2 \pm 14.1^{\mathrm{a}}$ \\
\hline PCB5 & $1.62 \pm 0.27^{\mathrm{a}}$ & $1.77 \pm 0.40^{\mathrm{a}}$ & $1.79 \pm 0.62^{\mathrm{a}}$ \\
\hline $\mathrm{PCC} 1$ & $5.11 \pm 1.28^{\mathrm{a}}$ & $7.89 \pm 3.27^{\mathrm{a}}$ & $6.43 \pm 3.48^{\mathrm{a}}$ \\
\hline CA2 & $3.06 \pm 0.71^{\mathrm{a}}$ & $3.54 \pm 1.14^{\mathrm{a}}$ & $3.79 \pm 2.17^{\mathrm{a}}$ \\
\hline QUE & $0.31 \pm 0.10^{\mathrm{a}}$ & $0 \pm 0^{\mathrm{b}}$ & $0 \pm 0^{\mathrm{b}}$ \\
\hline PHL & $0 \pm 0^{\mathrm{a}}$ & $0 \pm 0^{\mathrm{a}}$ & $0 \pm 0^{\mathrm{a}}$ \\
\hline CLA & $181 \pm 14^{\mathrm{a}}$ & $174 \pm 6^{\mathrm{a}}$ & $188 \pm 18^{\mathrm{a}}$ \\
\hline
\end{tabular}

Supplemental Table 6. Summary of 2016 Binet Rouge fruit, juice, and cider maturity data.

\begin{tabular}{|c|c|c|c|}
\hline \multirow[b]{2}{*}{ Parameter } & \multicolumn{3}{|c|}{ Harvest treatment } \\
\hline & $\mathrm{H} 1$ & $\mathrm{H} 2$ & $\mathrm{H} 3$ \\
\hline \multicolumn{4}{|l|}{ Fruit } \\
\hline Ethylene (ppm) & $3.65 \pm 2.96^{\mathrm{a}}$ & $3.12 \pm 2.57^{\mathrm{a}}$ & $10.01 \pm 5.06^{\mathrm{a}}$ \\
\hline SPI $(1-8)$ & $2.1 \pm 0.2^{\mathrm{b}}$ & $2.6 \pm 0.2^{\mathrm{ab}}$ & $3.2 \pm 0.2^{\mathrm{a}}$ \\
\hline Firmness (lbs) & - & $87.9 \pm 1.7^{\mathrm{a}}$ & $82.2 \pm 1.4^{\mathrm{a}}$ \\
\hline Weight $(\mathrm{g})$ & $46.1 \pm 1.7^{\mathrm{c}}$ & $52.3 \pm 1.8^{\mathrm{b}}$ & $60.5 \pm 2.0^{\mathrm{a}}$ \\
\hline Red color $(0-100 \%)$ & $24.0 \pm 2.9^{\mathrm{b}}$ & $50.1 \pm 3.7^{\mathrm{a}}$ & $46.0 \pm 3.4^{\mathrm{a}}$ \\
\hline \multicolumn{4}{|l|}{ Juice } \\
\hline SSC $\left({ }^{\circ}\right.$ Brix $)$ & $8.7 \pm 0.1^{\mathrm{a}}$ & $10.9 \pm 0.6^{\mathrm{a}}$ & $9.3 \pm 0.8^{\mathrm{a}}$ \\
\hline $\mathrm{pH}$ & $4.4 \pm 0.0^{\mathrm{a}}$ & $4.4 \pm 0.0^{\mathrm{a}}$ & $4.4 \pm 0.0^{\mathrm{a}}$ \\
\hline TA (g/L malic acid) & $1.6 \pm 0.2^{\mathrm{a}}$ & $1.6 \pm 0.2^{\mathrm{a}}$ & $1.6 \pm 0.2^{\mathrm{a}}$ \\
\hline SSC:TA & $5.6 \pm 0.7^{\mathrm{a}}$ & $6.8 \pm 0.7^{\mathrm{a}}$ & $5.8 \pm 0.4^{\mathrm{a}}$ \\
\hline PAN & $53 \pm 10^{\mathrm{a}}$ & $43 \pm 11^{\mathrm{a}}$ & $26 \pm 2^{\mathrm{a}}$ \\
\hline Polyphenols (mg/L GAE) & $1243 \pm 47^{\mathrm{a}}$ & $1029 \pm 62^{\mathrm{ab}}$ & $993 \pm 71^{\mathrm{b}}$ \\
\hline \multicolumn{4}{|l|}{ Cider } \\
\hline pH & $4.1 \pm 0.0^{\mathrm{a}}$ & $4.1 \pm 0.0^{\mathrm{a}}$ & $4.1 \pm 0.0^{\mathrm{a}}$ \\
\hline TA (g/mL malic acid) & $3.0 \pm 0.1^{\mathrm{a}}$ & $2.8 \pm 0.3^{\mathrm{a}}$ & $3.3 \pm 0.1^{\mathrm{a}}$ \\
\hline Ethanol $(\% \mathrm{v} / \mathrm{v})$ & $4.5 \pm 0.1^{\mathrm{a}}$ & $5.2 \pm 0.4^{\mathrm{a}}$ & $5.3 \pm 0.7^{\mathrm{a}}$ \\
\hline Polyphenols (mg/L GAE) & $1070 \pm 49^{\mathrm{a}}$ & $996 \pm 60^{\mathrm{a}}$ & $838 \pm 101^{\mathrm{a}}$ \\
\hline \multicolumn{4}{|l|}{ Individual Polyphenols } \\
\hline CAT & $2.95 \pm 1.56^{\mathrm{a}}$ & $4.04 \pm 2.41^{\mathrm{a}}$ & $0.99 \pm 0.16^{\mathrm{a}}$ \\
\hline EPI & $28.0 \pm 12.7^{\mathrm{a}}$ & $32.3 \pm 10.9^{\mathrm{a}}$ & $5.60 \pm 1.74^{\mathrm{a}}$ \\
\hline PCB1 & $3.51 \pm 1.77^{\mathrm{a}}$ & $2.38 \pm 0.69^{\mathrm{a}}$ & $0.58 \pm 0.28^{\mathrm{a}}$ \\
\hline PCB2 & $3.46 \pm 1.83^{\mathrm{a}}$ & $3.89 \pm 1.55^{\mathrm{a}}$ & $1.32 \pm 0.10^{\mathrm{a}}$ \\
\hline PCB5 & $0.48 \pm 0.29^{\mathrm{a}}$ & $0.67 \pm 0.23^{\mathrm{a}}$ & $0 \pm 0^{\mathrm{a}}$ \\
\hline PCC1 & $1.13 \pm 0.59^{\mathrm{a}}$ & $0.97 \pm 0.28^{\mathrm{a}}$ & $0.62 \pm 0.09^{\mathrm{a}}$ \\
\hline CA2 & $0.69 \pm 0.43^{\mathrm{a}}$ & $0.51 \pm 0.20^{\mathrm{a}}$ & $0.48 \pm 0.16^{\mathrm{a}}$ \\
\hline QUE & $0 \pm 0^{\mathrm{a}}$ & $0 \pm 0^{\mathrm{a}}$ & $0 \pm 0^{\mathrm{a}}$ \\
\hline PHL & $0 \pm 0^{\mathrm{a}}$ & $0 \pm 0^{\mathrm{a}}$ & $0 \pm 0^{\mathrm{a}}$ \\
\hline CLA & $335 \pm 17^{\mathrm{a}}$ & $346 \pm 22^{\mathrm{a}}$ & $278 \pm 10^{\mathrm{a}}$ \\
\hline
\end{tabular}


Supplemental Table 7. Summary of 2015 York fruit, juice, and cider storage data.

\begin{tabular}{|c|c|c|c|c|}
\hline \multirow[b]{2}{*}{ Parameter } & \multicolumn{4}{|c|}{ Storage treatment } \\
\hline & $\mathrm{CON}$ & S-1C & S-10C & $\mathrm{L}-1 \mathrm{C}$ \\
\hline \multicolumn{5}{|l|}{ Fruit } \\
\hline Ethylene (ppm) & $1.5 \pm 0.2^{\mathrm{c}}$ & $98.5 \pm 20.3^{b}$ & $236.6 \pm 36.0^{\mathrm{a}}$ & $71.6 \pm 8.6^{\mathrm{b}}$ \\
\hline SPI $(1-8)$ & $2.1 \pm 0.2^{\mathrm{c}}$ & $4.3 \pm 0.2^{\mathrm{b}}$ & $6.9 \pm 0.2^{\mathrm{a}}$ & $6.0 \pm 0.6^{\mathrm{a}}$ \\
\hline Firmness (lbs) & $89.4 \pm 0.9^{\mathrm{a}}$ & $81.8 \pm 1.3^{\mathrm{b}}$ & $70.3 \pm 1.3^{\mathrm{c}}$ & $64.9 \pm 1.3^{\mathrm{d}}$ \\
\hline Weight $(\mathrm{g})$ & $160 \pm 6^{\mathrm{a}}$ & $150 \pm 6^{\mathrm{ab}}$ & $156 \pm 6^{\mathrm{ab}}$ & $144 \pm 5^{\mathrm{b}}$ \\
\hline Red color $(0-100 \%)$ & $65.4 \pm 3.2^{\mathrm{a}}$ & $89.1 \pm 16.0^{\mathrm{a}}$ & $73.3 \pm 3.0^{\mathrm{a}}$ & $77.4 \pm 3.1^{\mathrm{a}}$ \\
\hline \multicolumn{5}{|l|}{ Juice } \\
\hline $\mathrm{SSC}\left({ }^{\circ} \mathrm{Brix}\right)$ & $9.7 \pm 0.2^{\mathrm{ab}}$ & $9.3 \pm 0.5^{\mathrm{b}}$ & $10.2 \pm 0.2^{\mathrm{ab}}$ & $10.8 \pm 0.3^{\mathrm{a}}$ \\
\hline $\mathrm{pH}$ & $3.7 \pm 0.0^{\mathrm{a}}$ & $3.4 \pm 0.1^{\mathrm{a}}$ & $3.4 \pm 0.2^{\mathrm{a}}$ & $3.4 \pm 0.1^{\mathrm{a}}$ \\
\hline TA (g/L malic acid) & $4.5 \pm 0.2^{\mathrm{ab}}$ & $4.8 \pm 0.2^{\mathrm{a}}$ & $2.7 \pm 0.2^{\mathrm{b}}$ & $3.3 \pm 0.2^{\mathrm{b}}$ \\
\hline SSC:TA & $2.2 \pm 0.1^{\mathrm{b}}$ & $2.0 \pm 0.2^{\mathrm{b}}$ & $3.9 \pm 0.4^{\mathrm{a}}$ & $3.3 \pm 0.2^{\mathrm{a}}$ \\
\hline PAN & $60 \pm 10^{\mathrm{a}}$ & $73 \pm 21^{\mathrm{a}}$ & $51 \pm 7^{\mathrm{a}}$ & $40 \pm 7^{\mathrm{a}}$ \\
\hline Polyphenols (mg/L GAE) & $455 \pm 24^{\mathrm{b}}$ & $547 \pm 18^{\mathrm{ab}}$ & $447 \pm 26^{\mathrm{b}}$ & $588 \pm 32^{\mathrm{a}}$ \\
\hline \multicolumn{5}{|l|}{ Cider } \\
\hline $\mathrm{pH}$ & $3.6 \pm 0.0^{\mathrm{a}}$ & $3.6 \pm 0.0^{\mathrm{a}}$ & $3.6 \pm 0.0^{\mathrm{a}}$ & $3.6 \pm 0.0^{\mathrm{a}}$ \\
\hline TA (g/mL malic acid) & $5.9 \pm 0.3^{\mathrm{a}}$ & $5.1 \pm 0.4^{\mathrm{a}}$ & $5.6 \pm 0.4^{\mathrm{a}}$ & $6.4 \pm 1.4^{\mathrm{a}}$ \\
\hline Ethanol $(\% \mathrm{v} / \mathrm{v})$ & $5.7 \pm 0.4^{\mathrm{a}}$ & $5.9 \pm 0.1^{\mathrm{a}}$ & $6.5 \pm 0.4^{\mathrm{a}}$ & $6.8 \pm 0.1^{\mathrm{a}}$ \\
\hline Polyphenols (mg/L GAE) & $260 \pm 15^{\mathrm{a}}$ & $363 \pm 33^{\mathrm{a}}$ & $286 \pm 22^{\mathrm{a}}$ & $315 \pm 27^{\mathrm{a}}$ \\
\hline \multicolumn{5}{|l|}{ Individual Polyphenols } \\
\hline CAT & $14.6 \pm 1.6^{\mathrm{ab}}$ & $19.9 \pm 1.7^{\mathrm{a}}$ & $13.5 \pm 1.3^{\mathrm{ab}}$ & $12.5 \pm 1.6^{\mathrm{b}}$ \\
\hline EPI & $86 \pm 5^{\mathrm{ab}}$ & $104 \pm 4^{\mathrm{a}}$ & $76 \pm 4^{\mathrm{b}}$ & $75 \pm 7^{\mathrm{b}}$ \\
\hline PCB1 & $39.8 \pm 5.1^{\mathrm{b}}$ & $68.1 \pm 5.9^{\mathrm{a}}$ & $34.4 \pm 3.8^{\mathrm{b}}$ & $37.7 \pm 6.7^{\mathrm{b}}$ \\
\hline PCB2 & $62.0 \pm 5.6^{\mathrm{ab}}$ & $89.0 \pm 5.5^{\mathrm{a}}$ & $49.9 \pm 4.1^{\mathrm{b}}$ & $59.2 \pm 9.1^{\mathrm{b}}$ \\
\hline PCB5 & $3.79 \pm 0.76^{\mathrm{a}}$ & $6.23 \pm 0.77^{\mathrm{a}}$ & $2.76 \pm 0.34^{\mathrm{a}}$ & $3.58 \pm 1.07^{\mathrm{a}}$ \\
\hline PCC1 & $18.1 \pm 5.8^{\mathrm{ab}}$ & $29.9 \pm 4.7^{\mathrm{a}}$ & $3.8 \pm 2.1^{\mathrm{b}}$ & $13.0 \pm 4.9^{\mathrm{ab}}$ \\
\hline CA2 & $2.4 \pm 0.8^{\mathrm{b}}$ & $11.2 \pm 1.3^{\mathrm{a}}$ & $2.4 \pm 1.1^{\mathrm{b}}$ & $6.5 \pm 1.3^{\mathrm{ab}}$ \\
\hline QUE & $2.99 \pm 0.39^{\mathrm{a}}$ & $2.11 \pm 0.11^{\mathrm{ab}}$ & $1.58 \pm 0.42^{\mathrm{bc}}$ & $0.76 \pm 0.30^{c}$ \\
\hline PHL & $0.34 \pm 0.17^{\mathrm{a}}$ & $0.44 \pm 0.04^{\mathrm{a}}$ & $0.31 \pm 0.20^{\mathrm{a}}$ & $0.64 \pm 0.08^{\mathrm{a}}$ \\
\hline CLA & $150 \pm 7^{\mathrm{a}}$ & $150 \pm 3^{\mathrm{a}}$ & $142 \pm 2^{\mathrm{a}}$ & $137 \pm 4^{\mathrm{a}}$ \\
\hline
\end{tabular}

Supplemental Table 8. Summary of 2015 Dabinett fruit, juice, and cider storage data.

\begin{tabular}{|c|c|c|c|c|}
\hline \multirow[b]{2}{*}{ Parameter } & \multicolumn{4}{|c|}{ Storage treatment } \\
\hline & $\mathrm{CON}$ & $\mathrm{S}-1 \mathrm{C}$ & S-10C & L-1C \\
\hline \multicolumn{5}{|l|}{ Fruit } \\
\hline Ethylene (ppm) & $19.6 \pm 5.7^{\mathrm{c}}$ & $51.5 \pm 16.0^{\mathrm{b}}$ & $304.0 \pm 41.8^{\mathrm{a}}$ & $239.2 \pm 28.1^{\mathrm{a}}$ \\
\hline SPI $(1-8)$ & $3.3 \pm 0.2^{\mathrm{d}}$ & $5.2 \pm 0.2^{\mathrm{c}}$ & $7.7 \pm 0.1^{\mathrm{b}}$ & $8.0 \pm 0.0^{\mathrm{a}}$ \\
\hline Firmness (lbs) & $126.8 \pm 1.3^{\mathrm{a}}$ & $100.1 \pm 2.2^{\mathrm{b}}$ & $71.2 \pm 1.8^{\mathrm{c}}$ & $74.3 \pm 0.9^{\mathrm{c}}$ \\
\hline Weight $(\mathrm{g})$ & $43 \pm 2^{\mathrm{b}}$ & $46 \pm 2^{\mathrm{ab}}$ & $51 \pm 3^{\mathrm{a}}$ & $51 \pm 2^{\mathrm{a}}$ \\
\hline Red color $(0-100 \%)$ & $47.3 \pm 3.0^{\mathrm{b}}$ & $56.7 \pm 3.9^{\mathrm{ab}}$ & $59.9 \pm 4.4^{\mathrm{ab}}$ & $61.3 \pm 3.7^{\mathrm{a}}$ \\
\hline \multicolumn{5}{|l|}{ Juice } \\
\hline $\mathrm{SSC}\left({ }^{\circ} \mathrm{Brix}\right)$ & $11.8 \pm 0.4^{\mathrm{b}}$ & $11.5 \pm 0.3^{b}$ & $11.6 \pm 0.7^{\mathrm{ab}}$ & $14.3 \pm 0.7^{\mathrm{a}}$ \\
\hline $\mathrm{pH}$ & $4.7 \pm 0.0^{\mathrm{a}}$ & $4.7 \pm 0.0^{\mathrm{a}}$ & $4.5 \pm 0.1^{\mathrm{ab}}$ & $4.4 \pm 0.0^{\mathrm{b}}$ \\
\hline TA (g/L malic acid) & $1.1 \pm 0.1^{\mathrm{a}}$ & $1.3 \pm 0.1^{\mathrm{a}}$ & $1.1 \pm 0.1^{\mathrm{a}}$ & $1.4 \pm 0.1^{\mathrm{a}}$ \\
\hline SSC:TA & $10.7 \pm 0.6^{\mathrm{a}}$ & $9.1 \pm 1.2^{\mathrm{a}}$ & $11.2 \pm 1.0^{\mathrm{a}}$ & $10.5 \pm 0.8^{\mathrm{a}}$ \\
\hline PAN & $38 \pm 8^{\mathrm{a}}$ & $34 \pm 10^{\mathrm{a}}$ & $30 \pm 9^{\mathrm{a}}$ & $29 \pm 8^{\mathrm{a}}$ \\
\hline Polyphenols (mg/L GAE) & $1760 \pm 112^{\mathrm{b}}$ & $1698 \pm 90^{\mathrm{b}}$ & $1800 \pm 163^{\mathrm{b}}$ & $2493 \pm 170^{\mathrm{a}}$ \\
\hline \multicolumn{5}{|l|}{ Cider } \\
\hline pH & $4.1 \pm 0.0^{\mathrm{a}}$ & $4.0 \pm 0.0^{\mathrm{a}}$ & $4.0 \pm 0.1^{\mathrm{a}}$ & $4.0 \pm 0.0^{\mathrm{a}}$ \\
\hline TA (g/mL malic acid) & $3.7 \pm 0.1^{\mathrm{a}}$ & $4.4 \pm 0.8^{\mathrm{a}}$ & $3.9 \pm 0.2^{\mathrm{a}}$ & $4.5 \pm 0.1^{\mathrm{a}}$ \\
\hline Ethanol $(\% \mathrm{v} / \mathrm{v})$ & $7.1 \pm 0.4^{\mathrm{a}}$ & $6.9 \pm 0.2^{\mathrm{a}}$ & $7.5 \pm 0.2^{\mathrm{a}}$ & $7.8 \pm 0.3^{\mathrm{a}}$ \\
\hline Polyphenols (mg/L GAE) & $2049 \pm 125^{\mathrm{a}}$ & $2104 \pm 96^{a}$ & $1997 \pm 91^{\mathrm{a}}$ & $2464 \pm 207^{\mathrm{a}}$ \\
\hline \multicolumn{5}{|l|}{ Individual Polyphenols } \\
\hline CAT & $52.7 \pm 2.2^{\mathrm{a}}$ & $55.1 \pm 3.4^{\mathrm{a}}$ & $55.3 \pm 2.4^{\mathrm{a}}$ & $56.2 \pm 3.4^{\mathrm{a}}$ \\
\hline EPI & $249 \pm 13^{\mathrm{a}}$ & $248 \pm 13^{\mathrm{a}}$ & $247 \pm 12^{\mathrm{a}}$ & $250 \pm 14^{\mathrm{a}}$ \\
\hline PCB1 & $202 \pm 9^{a}$ & $209 \pm 15^{\mathrm{a}}$ & $216 \pm 10^{\mathrm{a}}$ & $224 \pm 9^{a}$ \\
\hline PCB2 & $216 \pm 9^{a}$ & $224 \pm 13^{\mathrm{a}}$ & $223 \pm 11^{\mathrm{a}}$ & $233 \pm 6^{a}$ \\
\hline PCB5 & $38.0 \pm 2.1^{\mathrm{a}}$ & $40.5 \pm 3.4^{\mathrm{a}}$ & $43.1 \pm 2.2^{\mathrm{a}}$ & $48.1 \pm 3.0^{\mathrm{a}}$ \\
\hline PCC1 & $217 \pm 14^{\mathrm{a}}$ & $237 \pm 21^{\mathrm{a}}$ & $232 \pm 13^{\mathrm{a}}$ & $251 \pm 9^{\mathrm{a}}$ \\
\hline CA2 & $149 \pm 15^{\mathrm{a}}$ & $159 \pm 22^{\mathrm{a}}$ & $163 \pm 16^{\mathrm{a}}$ & $172 \pm 8^{\mathrm{a}}$ \\
\hline QUE & $1.08 \pm 0.44^{\mathrm{a}}$ & $0.92 \pm 0.35^{\mathrm{a}}$ & $1.26 \pm 0.32^{\mathrm{a}}$ & $1.21 \pm 0.11^{\mathrm{a}}$ \\
\hline PHL & $2.86 \pm 0.19^{\mathrm{a}}$ & $1.38 \pm 0.19^{\mathrm{a}}$ & $2.83 \pm 0.75^{\mathrm{a}}$ & $2.54 \pm 0.80^{\mathrm{a}}$ \\
\hline CLA & $200 \pm 5^{\mathrm{a}}$ & $205 \pm 5^{\mathrm{a}}$ & $204 \pm 7^{\mathrm{a}}$ & $222 \pm 5^{\mathrm{a}}$ \\
\hline
\end{tabular}




\begin{tabular}{|c|c|c|c|c|}
\hline \multirow[b]{2}{*}{ Parameter } & \multicolumn{4}{|c|}{ Storage treatment } \\
\hline & $\mathrm{CON}$ & S-1C & S-10C & L-1C \\
\hline \multicolumn{5}{|l|}{ Fruit } \\
\hline Ethylene (ppm) & $0.2 \pm 0.0^{\mathrm{c}}$ & $3.0 \pm 0.9^{\mathrm{c}}$ & $152.4 \pm 15.0^{\mathrm{a}}$ & $61.6 \pm 4.8^{\mathrm{b}}$ \\
\hline SPI $(1-8)$ & $3.2 \pm 0.1^{\mathrm{d}}$ & $4.6 \pm 0.1^{\mathrm{c}}$ & $7.5 \pm 0.1^{\mathrm{b}}$ & $7.8 \pm 0.0^{\mathrm{a}}$ \\
\hline Firmness (lbs) & $79.8 \pm 0.8^{\mathrm{a}}$ & $76.3 \pm 0.7^{\mathrm{b}}$ & $72.8 \pm 1.0^{\mathrm{c}}$ & $68.2 \pm 0.7^{\mathrm{d}}$ \\
\hline Weight $(\mathrm{g})$ & $138 \pm 4^{\mathrm{ab}}$ & $146 \pm 4^{\mathrm{a}}$ & $149 \pm 5^{\mathrm{a}}$ & $126 \pm 4^{\mathrm{b}}$ \\
\hline Green background color (1-4) & $2.3 \pm .1^{\mathrm{a}}$ & $1.8 \pm 0.1^{\mathrm{b}}$ & $1.5 \pm 0.1^{\mathrm{bc}}$ & $1.2 \pm 0.4^{\mathrm{c}}$ \\
\hline \multicolumn{5}{|l|}{ Juice } \\
\hline $\operatorname{SSC}\left({ }^{\circ}\right.$ Brix $)$ & $7.4 \pm 0.4^{\mathrm{b}}$ & $10.4 \pm 0.9^{\mathrm{ab}}$ & $13.1 \pm 0.7^{\mathrm{a}}$ & $12.0 \pm 0.7^{\mathrm{a}}$ \\
\hline $\mathrm{pH}$ & $3.5 \pm 0.0^{\mathrm{a}}$ & $3.7 \pm 0.2^{\mathrm{a}}$ & $3.7 \pm 0.0^{\mathrm{a}}$ & $3.6 \pm 0.0^{\mathrm{a}}$ \\
\hline TA (g/L malic acid) & $8.7 \pm 0.6^{\mathrm{a}}$ & $9.2 \pm 0.6^{\mathrm{a}}$ & $7.2 \pm 0.2^{\mathrm{a}}$ & $4.5 \pm 0.9^{\mathrm{b}}$ \\
\hline SSC:TA & $0.9 \pm 0.1^{\mathrm{b}}$ & $1.2 \pm 0.1^{\mathrm{b}}$ & $1.8 \pm 0.1^{\mathrm{ab}}$ & $3.1 \pm 0.7^{\mathrm{a}}$ \\
\hline PAN & $16 \pm 1^{\mathrm{ab}}$ & $19 \pm 1^{\mathrm{ab}}$ & $14 \pm 1^{\mathrm{b}}$ & $21 \pm 2^{\mathrm{a}}$ \\
\hline Polyphenols (mg/L GAE) & $505 \pm 32^{b}$ & $642 \pm 29^{\mathrm{ab}}$ & $624 \pm 47^{\mathrm{ab}}$ & $717 \pm 27^{\mathrm{a}}$ \\
\hline \multicolumn{5}{|l|}{ Cider } \\
\hline $\mathrm{pH}$ & $3.4 \pm 0.0^{\mathrm{c}}$ & $3.5 \pm 0.0^{\mathrm{b}}$ & $3.5 \pm 0.0^{\mathrm{b}}$ & $3.6 \pm 0.0^{\mathrm{a}}$ \\
\hline TA (g/mL malic acid) & $11.0 \pm 0.6^{\mathrm{a}}$ & $9.4 \pm 0.4^{\mathrm{ab}}$ & $8.6 \pm 0.4^{\mathrm{b}}$ & $8.2 \pm 0.5^{\mathrm{b}}$ \\
\hline Ethanol $(\% \mathrm{v} / \mathrm{v})$ & $4.6 \pm 0.2^{\mathrm{b}}$ & $6.6 \pm 0.3^{\mathrm{a}}$ & $6.5 \pm 0.4^{\mathrm{a}}$ & $6.5 \pm 0.6^{\mathrm{a}}$ \\
\hline Polyphenols (mg/L GAE) & $359 \pm 30^{\mathrm{a}}$ & $444 \pm 29^{\mathrm{a}}$ & $475 \pm 38^{\mathrm{a}}$ & $478 \pm 47^{\mathrm{a}}$ \\
\hline \multicolumn{5}{|l|}{ Individual Polyphenols } \\
\hline CAT & $3.53 \pm 1.46^{\mathrm{a}}$ & $5.62 \pm 1.99^{\mathrm{a}}$ & $9.52 \pm 1.28^{\mathrm{a}}$ & $5.85 \pm 2.57^{\mathrm{a}}$ \\
\hline EPI & $76 \pm 19^{\mathrm{a}}$ & $99 \pm 16^{\mathrm{a}}$ & $124 \pm 10^{\mathrm{a}}$ & $76 \pm 29^{\mathrm{a}}$ \\
\hline PCB1 & $11.9 \pm 3.8^{\mathrm{ab}}$ & $16.1 \pm 3.1^{\mathrm{ab}}$ & $19.6 \pm 2.3^{\mathrm{a}}$ & $6.1 \pm 2.2^{\mathrm{b}}$ \\
\hline PCB2 & $28.4 \pm 10.0^{\mathrm{a}}$ & $38.0 \pm 6.2^{\mathrm{a}}$ & $46.7 \pm 6.6^{\mathrm{a}}$ & $24.0 \pm 10.3^{\mathrm{a}}$ \\
\hline PCB5 & $2.21 \pm 1.10^{\mathrm{a}}$ & $3.42 \pm 0.99^{\mathrm{a}}$ & $4.90 \pm 0.94^{\mathrm{a}}$ & $3.26 \pm 1.37^{\mathrm{a}}$ \\
\hline PCC1 & $5.9 \pm 1.9^{\mathrm{a}}$ & $8.3 \pm 1.4^{\mathrm{a}}$ & $10.7 \pm 1.6^{\mathrm{a}}$ & $4.8 \pm 2.2^{\mathrm{a}}$ \\
\hline CA2 & $3.36 \pm 1.41^{\mathrm{a}}$ & $4.81 \pm 1.27^{\mathrm{a}}$ & $7.18 \pm 1.29^{\mathrm{a}}$ & $2.64 \pm 1.10^{\mathrm{a}}$ \\
\hline QUE & $0 \pm 0^{\mathrm{a}}$ & $0 \pm 0^{\mathrm{a}}$ & $0 \pm 0^{\mathrm{a}}$ & $0 \pm 0^{\mathrm{a}}$ \\
\hline PHL & $0 \pm 0^{\mathrm{a}}$ & $0 \pm 0^{\mathrm{a}}$ & $0 \pm 0^{\mathrm{a}}$ & $0 \pm 0^{\mathrm{a}}$ \\
\hline CLA & $260 \pm 7^{\mathrm{a}}$ & $275 \pm 16^{\mathrm{a}}$ & $283 \pm 9^{a}$ & $283 \pm 6^{\mathrm{a}}$ \\
\hline
\end{tabular}

Supplemental Table 10. Summary of 2016 Dabinett fruit, juice, and cider storage treatment.

\begin{tabular}{|c|c|c|c|c|}
\hline \multirow[b]{2}{*}{ Parameter } & \multicolumn{4}{|c|}{ Storage Treatment } \\
\hline & $\mathrm{CON}$ & $\mathrm{S}-1 \mathrm{C}$ & S-10C & $\mathrm{L}-1 \mathrm{C}$ \\
\hline \multicolumn{5}{|l|}{ Fruit } \\
\hline Ethylene (ppm) & $9 \pm 6^{\mathrm{b}}$ & $147 \pm 12^{\mathrm{b}}$ & $568 \pm 55^{\mathrm{a}}$ & $668 \pm 68^{a}$ \\
\hline SPI $(1-8)$ & $1.8 \pm 0.2^{\mathrm{c}}$ & $4.8 \pm 0.2^{\mathrm{b}}$ & $7.5 \pm 0.1^{\mathrm{a}}$ & $8.0 \pm 0.0^{\mathrm{a}}$ \\
\hline Firmness (lbs) & $96 \pm 1^{\mathrm{a}}$ & $88 \pm 1^{\mathrm{b}}$ & $67 \pm 1^{\mathrm{c}}$ & $72 \pm 1^{\mathrm{d}}$ \\
\hline Weight $(\mathrm{g})$ & $55 \pm 2^{\mathrm{a}}$ & $56 \pm 2^{\mathrm{a}}$ & $55 \pm 2^{\mathrm{a}}$ & $57 \pm 2^{\mathrm{a}}$ \\
\hline Red color $(0-100 \%)$ & $51.5 \pm 4.4^{\mathrm{ab}}$ & $57.7 \pm 3.1^{\mathrm{a}}$ & $58.3 \pm 3.2^{\mathrm{a}}$ & $42.2 \pm 3.0^{\mathrm{b}}$ \\
\hline \multicolumn{5}{|l|}{ Juice } \\
\hline SSC ( ${ }^{\circ}$ Brix $)$ & $6.3 \pm 0.7^{\mathrm{ab}}$ & $5.9 \pm 0.4^{\mathrm{b}}$ & $8.5 \pm 0.4^{\mathrm{ab}}$ & $9.4 \pm 1.2^{\mathrm{a}}$ \\
\hline $\mathrm{pH}$ & $4.7 \pm 0.0^{\mathrm{a}}$ & $4.5 \pm 0.0^{\mathrm{b}}$ & $4.5 \pm 0.1^{\mathrm{b}}$ & $4.5 \pm 0.0^{\mathrm{b}}$ \\
\hline TA (g/L malic acid) & $1.5 \pm 0.2^{\mathrm{a}}$ & $1.5 \pm 0.2^{\mathrm{a}}$ & $1.4 \pm 0.2^{\mathrm{a}}$ & $2.0 \pm 0.2^{\mathrm{a}}$ \\
\hline SSC:TA & $4.3 \pm 0.4^{\mathrm{a}}$ & $4.1 \pm 0.7^{\mathrm{a}}$ & $6.6 \pm 1.2^{\mathrm{a}}$ & $4.8 \pm 0.4^{\mathrm{a}}$ \\
\hline PAN & $52 \pm 9^{\mathrm{a}}$ & $54 \pm 12^{\mathrm{a}}$ & $50 \pm 17^{\mathrm{a}}$ & $45 \pm 7^{\mathrm{a}}$ \\
\hline Polyphenols (mg/L GAE) & $1278 \pm 104^{\mathrm{b}}$ & $1710 \pm 56^{\mathrm{b}}$ & $2603 \pm 134^{\mathrm{a}}$ & $2645 \pm 162^{\mathrm{a}}$ \\
\hline \multicolumn{5}{|l|}{ Cider } \\
\hline $\mathrm{pH}$ & $4.3 \pm 0.0^{\mathrm{a}}$ & $4.1 \pm 0.0^{\mathrm{b}}$ & $4.1 \pm 0.0^{\mathrm{b}}$ & $4.1 \pm 0.0^{\mathrm{b}}$ \\
\hline TA (mg/L malic acid) & $2.2 \pm 0.1^{\mathrm{c}}$ & $4.1 \pm 0.1^{\mathrm{a}}$ & $3.3 \pm 0.2^{\mathrm{b}}$ & $3.5 \pm 0.1^{\mathrm{bc}}$ \\
\hline Ethanol $(\% \mathrm{v} / \mathrm{v})$ & $4.7 \pm 0.2^{\mathrm{b}}$ & $4.7 \pm 0.5^{\mathrm{b}}$ & $5.9 \pm 0.2^{\mathrm{ab}}$ & $6.2 \pm 0.2^{\mathrm{a}}$ \\
\hline Polyphenols (mg/L GAE) & $1120 \pm 104^{\mathrm{c}}$ & $1308 \pm 173^{\mathrm{bc}}$ & $1688 \pm 112^{\mathrm{ab}}$ & $1871 \pm 77^{\mathrm{a}}$ \\
\hline \multicolumn{5}{|l|}{ Individual Polyphenols } \\
\hline CAT & $22.3 \pm 1.5^{\mathrm{b}}$ & $37.0 \pm 5.2^{\mathrm{ab}}$ & $47.3 \pm 3.3^{\mathrm{a}}$ & $51.3 \pm 3.8^{\mathrm{a}}$ \\
\hline EPI & $224 \pm 7^{\mathrm{b}}$ & $284 \pm 25^{\mathrm{ab}}$ & $325 \pm 15^{\mathrm{a}}$ & $344 \pm 17^{\mathrm{a}}$ \\
\hline PCB1 & $41.7 \pm 4.6^{\mathrm{b}}$ & $63.7 \pm 10.8^{\mathrm{ab}}$ & $60.4 \pm 20.4^{\mathrm{ab}}$ & $98.7 \pm 11.8^{\mathrm{a}}$ \\
\hline PCB2 & $88 \pm 5^{\mathrm{c}}$ & $121 \pm 14^{\mathrm{bc}}$ & $154 \pm 9^{\mathrm{ab}}$ & $163 \pm 9^{\mathrm{a}}$ \\
\hline PCB5 & $5.7 \pm 0.8^{c}$ & $15.1 \pm 3.0^{\mathrm{bc}}$ & $24.9 \pm 2.4^{\mathrm{ab}}$ & $27.8 \pm 2.6^{\mathrm{a}}$ \\
\hline PCC1 & $23.4 \pm 1.7^{\mathrm{b}}$ & $40.8 \pm 7.0^{\mathrm{ab}}$ & $52.7 \pm 1.7^{\mathrm{a}}$ & $57.6 \pm 4.4^{\mathrm{a}}$ \\
\hline CA2 & $20.6 \pm 2.1^{\mathrm{b}}$ & $42.6 \pm 9.0^{\mathrm{ab}}$ & $70.3 \pm 8.2^{\mathrm{a}}$ & $71.9 \pm 8.7^{\mathrm{a}}$ \\
\hline QUE & $0 \pm 0^{\mathrm{a}}$ & $0 \pm 0^{\mathrm{a}}$ & $0 \pm 0^{\mathrm{a}}$ & $0 \pm 0^{\mathrm{a}}$ \\
\hline PHL & $0.48 \pm 0.16^{\mathrm{a}}$ & $0.81 \pm 0.62^{\mathrm{a}}$ & $0.93 \pm 0.37^{\mathrm{a}}$ & $0.06 \pm 0.06^{\mathrm{a}}$ \\
\hline CLA & $292 \pm 10^{\mathrm{b}}$ & $330 \pm 10^{\mathrm{ab}}$ & $270 \pm 15^{\mathrm{a}}$ & $370 \pm 10^{\mathrm{a}}$ \\
\hline
\end{tabular}


Supplemental Table 11. Summary of 2016 Binet Rouge fruit, juice, and cider storage treatment.

\begin{tabular}{|c|c|c|c|c|}
\hline \multirow[b]{2}{*}{ Parameter } & \multicolumn{4}{|c|}{ Storage treatment } \\
\hline & $\mathrm{CON}$ & S-1C & S-10C & L-1C \\
\hline \multicolumn{5}{|l|}{ Fruit } \\
\hline Ethylene (ppm) & $2 \pm 2^{c}$ & $15 \pm 2^{\mathrm{b}}$ & $44 \pm 11^{\mathrm{a}}$ & $24 \pm 6^{\mathrm{b}}$ \\
\hline SII $(1-8)$ & $2.9 \pm 0.2^{\mathrm{c}}$ & $4.3 \pm 0.3^{\mathrm{b}}$ & $7.4 \pm 0.1^{\mathrm{a}}$ & $7.7 \pm 0.1^{\mathrm{a}}$ \\
\hline Firmness (lbs) & $86 \pm 2^{\mathrm{a}}$ & $86 \pm 2^{\mathrm{a}}$ & $73 \pm 2^{\mathrm{b}}$ & $73 \pm 2^{\mathrm{b}}$ \\
\hline Weight $(\mathrm{g})$ & $52 \pm 2^{\mathrm{a}}$ & $51 \pm 2^{\mathrm{a}}$ & $46 \pm 2^{\mathrm{a}}$ & $46 \pm 2^{\mathrm{b}}$ \\
\hline Red color $(0-100 \%)$ & $38.5 \pm 3.9^{\mathrm{ab}}$ & $47.7 \pm 3.9^{\mathrm{a}}$ & $47.6 \pm 5.0^{\mathrm{a}}$ & $30.2 \pm 3.6^{\mathrm{b}}$ \\
\hline \multicolumn{5}{|l|}{ Juice } \\
\hline $\operatorname{SSC}\left({ }^{\circ}\right.$ Brix $)$ & $5.7 \pm 0.3^{\mathrm{c}}$ & $7.4 \pm 1.1^{\mathrm{bc}}$ & $9.9 \pm 0.4^{\mathrm{ab}}$ & $11.9 \pm 1.2^{\mathrm{a}}$ \\
\hline $\mathrm{pH}$ & $4.4 \pm 0.0^{\mathrm{ab}}$ & $4.3 \pm 0.0^{\mathrm{b}}$ & $4.4 \pm 0.0^{\mathrm{ab}}$ & $4.6 \pm 0.0^{\mathrm{a}}$ \\
\hline TA (g/L malic acid) & $2.4 \pm 0.3^{\mathrm{a}}$ & $2.4 \pm 0.5^{\mathrm{a}}$ & $2.1 \pm 0.1^{\mathrm{a}}$ & $1.6 \pm 0.2^{\mathrm{a}}$ \\
\hline SSC:TA & $2.5 \pm 0.3^{\mathrm{b}}$ & $3.4 \pm 0.5^{\mathrm{b}}$ & $4.7 \pm 0.1^{\mathrm{b}}$ & $7.5 \pm 0.9^{\mathrm{a}}$ \\
\hline PAN & $51 \pm 7^{\mathrm{a}}$ & $54 \pm 10^{\mathrm{a}}$ & $27 \pm 8^{\mathrm{a}}$ & $34 \pm 8^{\mathrm{a}}$ \\
\hline Polyphenols (mg/L GAE) & $1225 \pm 211^{\mathrm{a}}$ & $1286 \pm 110^{\mathrm{a}}$ & $1931 \pm 204^{\mathrm{a}}$ & $1973 \pm 242^{\mathrm{a}}$ \\
\hline \multicolumn{5}{|l|}{ Cider } \\
\hline $\mathrm{pH}$ & $4.1 \pm 0.0^{\mathrm{a}}$ & $4.1 \pm 0.0^{\mathrm{a}}$ & $4.0 \pm 0.1^{\mathrm{a}}$ & $4.1 \pm 0.0^{\mathrm{a}}$ \\
\hline TA (mg/L malic acid) & $4.4 \pm 0.1^{\mathrm{a}}$ & $4.5 \pm 0.1^{\mathrm{a}}$ & $2.5 \pm 0.4^{\mathrm{b}}$ & $2.9 \pm 0.2^{\mathrm{b}}$ \\
\hline Ethanol $(\% \mathrm{v} / \mathrm{v})$ & $3.9 \pm 0.1^{\mathrm{c}}$ & $4.5 \pm 0.3^{\mathrm{bc}}$ & $6.4 \pm 0.9^{\mathrm{ab}}$ & $7.9 \pm 0.4^{\mathrm{a}}$ \\
\hline Polyphenols (mg/L GAE) & $807 \pm 42^{\mathrm{b}}$ & $899 \pm 43^{b}$ & $1344 \pm 91^{\mathrm{a}}$ & $1567 \pm 65^{a}$ \\
\hline \multicolumn{5}{|l|}{ Individual Polyphenols } \\
\hline CAT & $7.7 \pm 3.2^{\mathrm{b}}$ & $11.2 \pm 2.5^{\mathrm{b}}$ & $33.8 \pm 0.3^{\mathrm{a}}$ & $29.1 \pm 1.6^{\mathrm{a}}$ \\
\hline EPI & $62 \pm 17^{b}$ & $78 \pm 14^{\mathrm{b}}$ & $170 \pm 3^{\mathrm{a}}$ & $155 \pm 5^{\mathrm{a}}$ \\
\hline PCB1 & $5.4 \pm 2.6^{\mathrm{b}}$ & $5.6 \pm 1.4^{\mathrm{b}}$ & $25.4 \pm 1.5^{\mathrm{a}}$ & $19.6 \pm 1.6^{\mathrm{a}}$ \\
\hline PCB2 & $10.6 \pm 5.4^{\mathrm{b}}$ & $11.7 \pm 4.7^{\mathrm{b}}$ & $60.9 \pm 2.0^{\mathrm{a}}$ & $54.0 \pm 5.1^{\mathrm{a}}$ \\
\hline PCB5 & $1.25 \pm 0.33^{\mathrm{b}}$ & $1.59 \pm 0.23^{\mathrm{b}}$ & $4.92 \pm 0.50^{\mathrm{a}}$ & $4.59 \pm 0.41^{\mathrm{a}}$ \\
\hline PCC1 & $2.4 \pm 1.2^{\mathrm{b}}$ & $3.3 \pm 0.8^{\mathrm{b}}$ & $17.3 \pm 0.7^{\mathrm{a}}$ & $14.7 \pm 1.5^{\mathrm{a}}$ \\
\hline CA2 & $1.4 \pm 0.7^{\mathrm{b}}$ & $1.7 \pm 0.5^{\mathrm{b}}$ & $14.3 \pm 0.7^{\mathrm{a}}$ & $10.7 \pm 1.4^{\mathrm{a}}$ \\
\hline QUE & $0 \pm 0^{\mathrm{a}}$ & $0 \pm 0^{\mathrm{a}}$ & $0 \pm 0^{\mathrm{a}}$ & $0 \pm 0^{\mathrm{a}}$ \\
\hline PHL & $1.21 \pm 0.43^{\mathrm{a}}$ & $0.53 \pm 0.26^{\mathrm{a}}$ & $1.56 \pm 0.51^{\mathrm{a}}$ & $0.16 \pm 0.10^{\mathrm{a}}$ \\
\hline CLA & $372 \pm 13^{\mathrm{b}}$ & $357 \pm 18^{\mathrm{b}}$ & $428 \pm 9^{\mathrm{a}}$ & $447 \pm 3^{\mathrm{a}}$ \\
\hline
\end{tabular}

